Prepared in cooperation with the Montana Department of Environmental Quality

\title{
Travel Times, Streamilow Velocities, and Dispersion Rates in the Yellowstone River. Montana
}

Scientific Investigations Report 2009-5261 
Cover. Looking downstream at the non-toxic dye plume from the Miles City Bridge over the Yellowstone River, near Miles City, Montana. Photograph by Peter M. McCarthy, U.S. Geological Survey, taken September 23, 2008. 


\section{Travel Times, Streamflow Velocities, and Dispersion Rates in the Yellowstone River, Montana}

By Peter M. McCarthy

Prepared in cooperation with the Montana Department of Environmental Quality

Scientific Investigations Report 2009-5261 


\title{
U.S. Department of the Interior \\ KEN SALAZAR, Secretary \\ U.S. Geological Survey \\ Marcia K. McNutt, Director
}

\section{U.S. Geological Survey, Reston, Virginia: 2009}

\author{
For more information on the USGS — the Federal source for science about the Earth, its natural and living resources, \\ natural hazards, and the environment, visit http://www.usgs.gov or call 1-888-ASK-USGS \\ For an overview of USGS information products, including maps, imagery, and publications, \\ visit http://www.usgs.gov/pubprod \\ To order this and other USGS information products, visit http://store.usgs.gov
}

\begin{abstract}
Any use of trade, product, or firm names is for descriptive purposes only and does not imply endorsement by the U.S. Government.

Although this report is in the public domain, permission must be secured from the individual copyright owners to reproduce any copyrighted materials contained within this report.
\end{abstract}

Suggested citation:

McCarthy, P.M., 2009, Travel times, streamflow velocities, and dispersion rates in the Yellowstone River, Montana: U.S. Geological Survey Scientific Investigations Report 2009-5261, 25 p. 


\section{Contents}

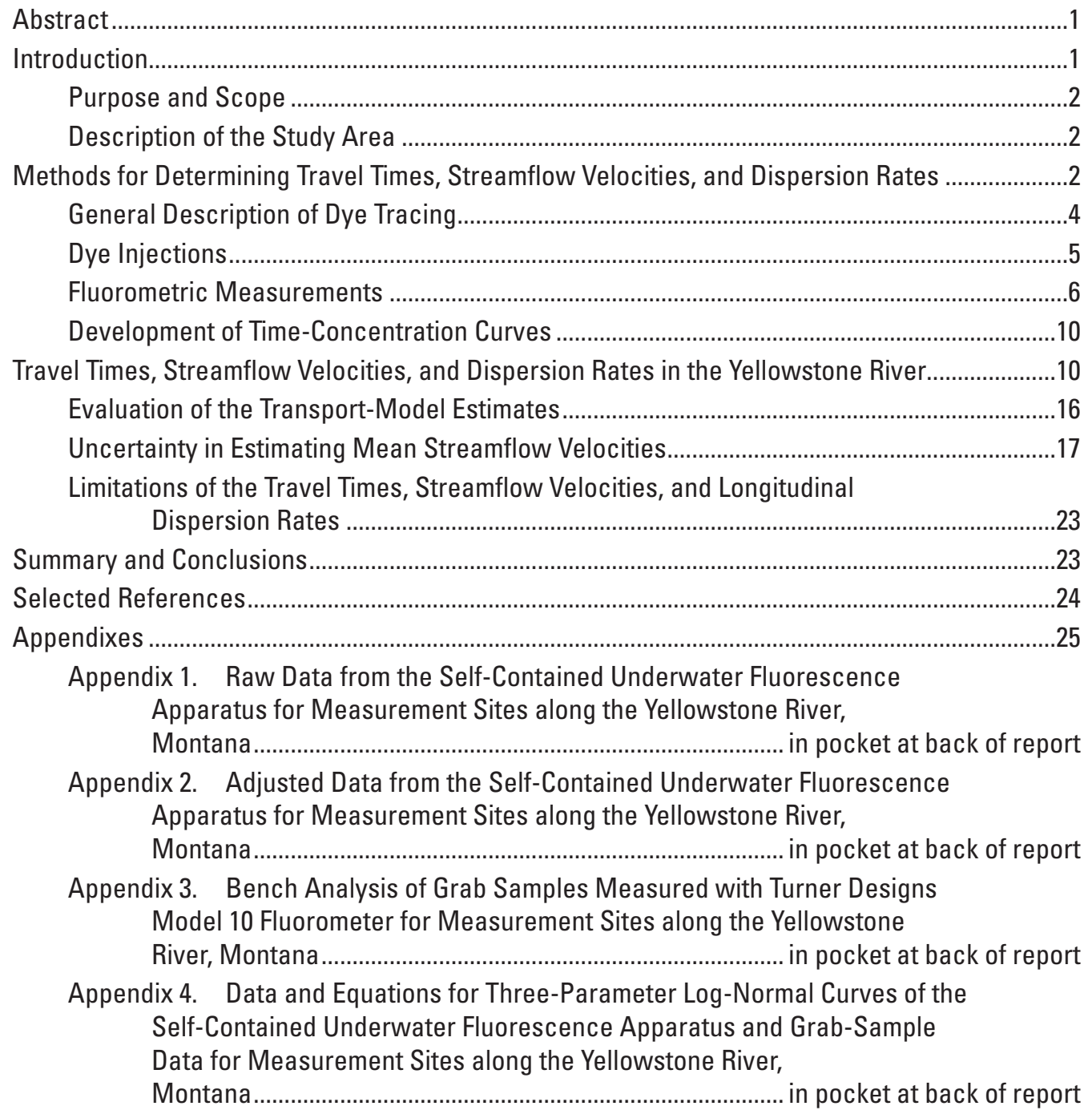

\section{Figures}

1. Map showing locations of the study area and sites used for dye injection or measuring, Yellowstone River, Montana ....................................................................

2. Graph showing a typical time-concentration curve for the movement of dye past a fixed measurement point downstream from a dye injection.....................................5

3-6. Maps showing:

3. Location of subreach for dye injection at Lockwood Bridge, Montana .....................7

4. Location of subreach for dye injection at Myers Bridge, Montana ...........................8

5. Location of subreach for dye injection at Cartersville Dam, Montana......................8

6. Location of subreach for dye injection at Miles City Bridge, Montana.....................9

7-18. Graphs showing:

7. Concentration of Rhodamine WT dye at Pompeys Bridge, Montana 
8. Rhodamine WT dye time-concentration curve fit to data from the discrete samples collected at Forsyth Bridge after September 29 dye injection at Lockwood Bridge, Montana.

9. Time-concentration curves for Rhodamine WT dye injected at Lockwood Bridge, Montana.

10. Time-concentration curves for Rhodamine WT dye injected at Myers Bridge, Montana.

11. Time-concentration curves for Rhodamine WT dye injected at Cartersville Dam, Montana

12. Time-concentration curves for Rhodamine WT dye injected at Miles City Bridge, Montana

13. Relation between travel times of the peak concentration and durations of the dye plume for the Yellowstone River, Montana.

14. Calculated and estimated velocity data for subreach upstream from each site

15. Calculated velocity of the centroid of the dye plume from Lockwood Bridge to Huntley Bridge and the velocity-streamflow relations developed from the transport model (McCarthy, 2006) and routine streamflow measurements for the Yellowstone River at Billings, Montana (gaging station 06214500).

16. Calculated velocity of the centroid of the dye plume from Forsyth Bridge to Cartersville Dam and the velocity-streamflow relations developed from the transport model (McCarthy, 2006) and routine streamflow measurements for the Yellowstone River at Forsyth, Montana (gaging station 06295000)

17. Calculated velocity of the centroid of the dye plume from Fort Keogh

Bridge to Kinsey Bridge and the velocity-streamflow relations developed from the transport model (McCarthy, 2006) and routine streamflow measurements for the Yellowstone River at Miles City, Montana (gaging station 06309000)

18. Calculated velocity of the centroid of the dye plume from Fallon Bridge to Glendive Bridge and the velocity-streamflow relations developed from the transport model (McCarthy, 2006) and routine streamflow measurements for the Yellowstone River at Glendive, Montana (gaging station 06327500)

\section{Tables}

1. Injection and measurement sites along the Yellowstone River, Montana.

2. Optimal mixing length for each injection site along the Yellowstone River, Montana

3. Travel-time data and mean streamflow velocities for the Yellowstone River, Montana

4. Longitudinal dispersion rates for the Yellowstone River, Montana..

5. Calculated and estimated streamflow velocities for each subreach within the study area, Yellowstone River, Montana.

6. Estimated and measured peak Rhodamine WT dye concentrations for each subreach within the study area, Yellowstone River, Montana. 


\section{Conversion Factors, Acronyms, and Abbreviated Units}

\begin{tabular}{lcl}
\hline Multiply & By & To obtain \\
\hline \multicolumn{3}{c}{ Length } \\
\hline mile $(\mathrm{mi})$ & 1.609 & kilometer $(\mathrm{km})$ \\
\hline \multicolumn{3}{c}{ Volume } \\
\hline gallon $(\mathrm{gal})$ & 3.785 & liter $(\mathrm{L})$ \\
\hline \multicolumn{3}{c}{ Flow rate } \\
\hline foot per second $(\mathrm{ft} / \mathrm{s})$ & 0.3048 & meter per second $(\mathrm{m} / \mathrm{s})$ \\
cubic foot per second $\left(\mathrm{ft}^{3} / \mathrm{s}\right)$ & 0.02832 & cubic meter per second $\left(\mathrm{m}^{3} / \mathrm{s}\right)$ \\
\hline \multicolumn{3}{c}{ Mass } \\
\hline pound, avoirdupois $(\mathrm{lb})$ & 0.4536 \\
\hline & Hydraulic gradient & \\
\hline foot per mile $(\mathrm{ft} / \mathrm{mi})$ & 0.1894 & meter per kilometer $(\mathrm{m} / \mathrm{km})$ \\
\hline
\end{tabular}

Temperature in degrees Celsius $\left({ }^{\circ} \mathrm{C}\right)$ may be converted to degrees Fahrenheit $\left({ }^{\circ} \mathrm{F}\right)$ as follows:

$$
{ }^{\circ} \mathrm{F}=\left(1.8 x^{\circ} \mathrm{C}\right)+32
$$

Horizontal coordinate information is referenced to both the North American Datum of 1927 (NAD 27) and the North American Datum of 1983 (NAD 83).

Concentrations of chemical constituents in water are given in milligrams per liter $(\mathrm{mg} / \mathrm{L})$ and micrograms per liter $(\mu \mathrm{g} / \mathrm{L})$.

\section{Acronyms used in this report}

$\begin{array}{ll}\text { ADCP } & \text { acoustic Doppler current profiler } \\ \text { CD-ROM } & \text { Compact Disk-Read-Only Memory } \\ \text { RWT } & \text { Rhodamine WT } \\ \text { SCUFA } & \text { Self-Contained Underwater Fluorescence Apparatus } \\ \text { USGS } & \text { U.S. Geological Survey }\end{array}$

\section{Abbreviated units used in this report}

$\begin{array}{ll}\mathrm{ft} / \mathrm{mi} & \text { foot (feet) per mile } \\ \mathrm{ft} / \mathrm{s} & \text { foot (feet) per second } \\ \mathrm{ft}^{3} / \mathrm{s} & \text { cubic foot (feet) per second } \\ \mathrm{L} & \text { liter } \\ \mathrm{mg} / \mathrm{L} & \text { milligram(s) per liter } \\ \mu \mathrm{g} / \mathrm{L} & \text { microgram(s) per liter } \\ \text { NTU } & \text { nephelometric turbidity units }\end{array}$





\title{
Travel Times, Streamflow Velocities, and Dispersion Rates in the Yellowstone River, Montana
}

\author{
By Peter M. McCarthy
}

\section{Abstract}

The Yellowstone River is a vital natural resource to the residents of southeastern Montana and is a primary source of water for irrigation and recreation and the primary source of municipal water for several cities. The Yellowstone River valley is the primary east-west transportation corridor through southern Montana. This complex of infrastructure makes the Yellowstone River especially vulnerable to accidental spills from various sources such as tanker cars and trucks. In 2008, the U.S. Geological Survey (USGS), in cooperation with the Montana Department of Environmental Quality, initiated a dye-tracer study to determine instream travel times, streamflow velocities, and dispersion rates for the Yellowstone River from Lockwood to Glendive, Montana. The purpose of this report is to describe the results of this study and summarize data collected at each of the measurement sites between Lockwood and Glendive. This report also compares the results of this study to estimated travel times from a transport model developed by the USGS for a previous study. For this study, Rhodamine WT dye was injected at four locations in late September and early October 2008 during reasonably steady streamflow conditions. Streamflows ranged from 3,490 to 3,770 cubic feet per second upstream from the confluence of the Bighorn River and ranged from 6,520 to 7,570 cubic feet per second downstream from the confluence of the Bighorn River.

Mean velocities were calculated for each subreach between measurement sites for the leading edge, peak concentration, centroid, and trailing edge at 10 percent of the peak concentration. Calculated velocities for the centroid of the dye plume for subreaches that were completely laterally mixed ranged from 1.83 to $3.18 \mathrm{ft} / \mathrm{s}$ within the study reach from Lockwood Bridge to Glendive Bridge. The mean of the completely mixed centroid velocity for the entire study reach, excluding the subreach between Forsyth Bridge and Cartersville Dam, was $2.80 \mathrm{ft} / \mathrm{s}$. Longitudinal dispersion rates of the dye plume for this study ranged from $0.06 \mathrm{ft} / \mathrm{s}$ for the subreach upstream from Forsyth Bridge to $2.25 \mathrm{ft} / \mathrm{s}$ for the subreach upstream from Calyspo Bridge for subreaches where the dye was completely laterally mixed. A relation was determined between travel time of the peak concentration and time for the dye plume to pass a site (duration). This relation can be used to estimate when the receding concentration of a potential contaminant reaches 10 percent of its peak concentration for accidental spills into the Yellowstone River.

Data from this dye-tracer study were used to evaluate velocity and concentration estimates from a transport model developed as part of an earlier USGS study. Comparison of the estimated and calculated velocities for the study reach indicate that the transport model estimates the velocities of the Yellowstone River between Huntley Bridge and Glendive Bridge with reasonable accuracy. Velocities of the peak concentration of the dye plume calculated for this study averaged 10 percent faster than the most probable velocities and averaged 12 percent slower than the maximum probable velocities estimated from the transport model. Peak Rhodamine WT dye concentrations were consistently lower than the transport model estimates except for the most upstream subreach of each dye injection. The most upstream subreach of each dye injection is expected to have a higher concentration because of incomplete lateral mixing. Lower measured peak concentrations for all other sites were expected because Rhodamine WT dye deteriorates when exposed to sunlight and will sorb onto the streambanks and stream bottom.

Velocity-streamflow relations developed by using routine streamflow measurements at USGS gaging stations and the transport model can be used to estimate mean streamflow velocities throughout a range of streamflows. The variation in these velocity-streamflow relations emphasizes the uncertainty in estimating the mean streamflow velocity for streamflows outside of the streamflows measured in this study.

\section{Introduction}

The Yellowstone River is a vital natural resource to the residents of southeastern Montana. The River originates in Yellowstone National Park and flows about 545 river miles to the Montana-North Dakota State line (fig. 1). The Yellowstone River is important to the economy of this region as a primary source of water for irrigation and recreation, and is the primary source of municipal water for the cities of Laurel, Billings, Lockwood, Forsyth, Miles City, and Glendive. Other communities along the Yellowstone River obtain their 
municipal water from shallow alluvial aquifers adjacent to the Yellowstone River and its tributaries.

The Yellowstone River valley is the primary east-west transportation corridor through southern Montana. Transportation infrastructure within this corridor includes Interstate Highways I-90 and I-94; Montana Rail Link and Burlington Northern Santa Fe Railroads; and many state highways, county roads, and city streets. Numerous roadways and railways cross over the Yellowstone River or are adjacent to the Yellowstone River. This complex of infrastructure makes the Yellowstone River especially vulnerable to accidental spills from various sources such as tanker cars and trucks. Knowledge of instream travel times, streamflow velocities, dispersion, and dilution of contaminant concentrations is a requirement for effective emergency response to a contaminant spill into the Yellowstone River. Additionally, travel times, streamflow velocites, and longitudinal dispersion rates are needed to calibrate hydraulic and water-quality models of the Yellowstone River.

McCarthy (2006) developed a transport model to provide estimates of instream travel times and concentrations of a soluble compound in the Yellowstone River. This model utilizes regression equations developed by Jobson (1999), which were based on empirical time-of-travel data from numerous dye-tracer studies conducted throughout the United States. The model developed by McCarthy (2006) was not calibrated because travel-time data were not available. However, precipitation-driven flood-wave velocities were estimated using hydrographs, and these velocities were used to constrain the model in lieu of measured travel-time data. In 2008, the U.S. Geological Survey (USGS), in cooperation with the Montana Department of Environmental Quality, initiated a dye-tracer study to determine travel times, streamflow velocities, and longitudinal dispersion rates for the Yellowstone River in order to validate the transport model and to calibrate a water-quality model for the river.

\section{Purpose and Scope}

The purpose of this report is to describe the results of a study to determine travel times, streamflow velocities, and longitudinal dispersion rates for a reach of the Yellowstone River for one streamflow condition. For this study, Rhodamine WT (RWT) dye was injected at four locations in late September and early October 2008. Dye concentrations were measured at an average of four sites downstream from each dye injection. These data were used to determine travel times, streamflow velocities, and longitudinal dispersion rates for a 266-mi reach of the Yellowstone River from Lockwood to Glendive. Included in this report are the time-of-travel data collected during the dye tracer study, analysis of the data to determine streamflow velocities and longitudinal dispersion rates, and comparisons of the data to estimates from the transport model developed by McCarthy (2006). The traveltime data collected and analyzed for this study are in appendixes 1-4 [Compact Disk-Read Only Memory (CD-ROM) located in the inside back cover].

\section{Description of the Study Area}

The upstream end of the study reach is downstream from Billings, Montana, where U.S. Highway 87 crosses the Yellowstone River (Lockwood Bridge) at river mile 360.6 (table 1). The study reach extends approximately 266 river miles downstream to the West Bell Street Bridge (Glendive Bridge), river mile 94.6, in Glendive, Montana (fig.1) [river miles derived from the Montana Department of Natural Resources and Conservation (1976) river mile index of the Yellowstone River and Google, Inc. (2008)]. Within the study reach, three major tributaries join the Yellowstone River: Bighorn River, Tongue River, and Powder River. Mean annual streamflow for the Yellowstone River at Billings, based on 73 years of record from 1928 to 2002, is $6,970 \mathrm{ft}^{3} / \mathrm{s}$. Mean annual streamflow for the Yellowstone River at Glendive, based on 10 years of record from 1897 to 1934 , is $13,300 \mathrm{ft}^{3} / \mathrm{s}$. Mean annual streamflow for the Bighorn River is $3,860 \mathrm{ft}^{3} / \mathrm{s}$, whereas the mean annual streamflows for the Tongue River and Powder River are $409 \mathrm{ft}^{3} / \mathrm{s}$, and $576 \mathrm{ft}^{3} / \mathrm{s}$, respectively (McCarthy, 2005). The channel slope of the Yellowstone River within the study reach ranged from $10.6 \mathrm{ft} / \mathrm{mi}$ at Billings to $3.2 \mathrm{ft} / \mathrm{mi}$ at Glendive (McCarthy, 2006). The channel substrate changes from large cobbles mixed with large gravel and small boulders at Billings to gravel and sand at Glendive.

Throughout the study reach, the Yellowstone River is used for municipal-water supply, irrigation supply, and recreation. Forsyth, Miles City, and Glendive are three communities within this study reach that obtain their municipal-water supply from the Yellowstone River. Lockwood and Billings obtain their municipal-water supply from the Yellowstone River upstream from the study reach. Three low-head dams located upstream from Huntley, downstream from Pompeys Bridge, and at Forsyth are used to divert water for irrigation in the river valley. Pumps also are used at other locations along the river to pump water from the Yellowstone River for irrigation. The scenic beauty and natural conditions along the river support a major riparian corridor for numerous wildlife species, recreational fishing, hunting, and paddling.

\section{Methods for Determining Travel Times, Streamflow Velocities, and Dispersion Rates}

Dye tracers are commonly used for time-of-travel studies because the dyes are water soluble and behave in the same manner as the water particles. A measure of the movement of the dye tracer will, in effect, be a measure of the movement of the fluid in the stream and of its dispersion characteristics (Kilpatrick and Wilson, 1989). Dispersion and mixing of the injected dye tracer occurs in all three dimensions of the channel: vertical, lateral, and longitudinal. The speed at which mixing of the dye occurs depends upon hydraulic 

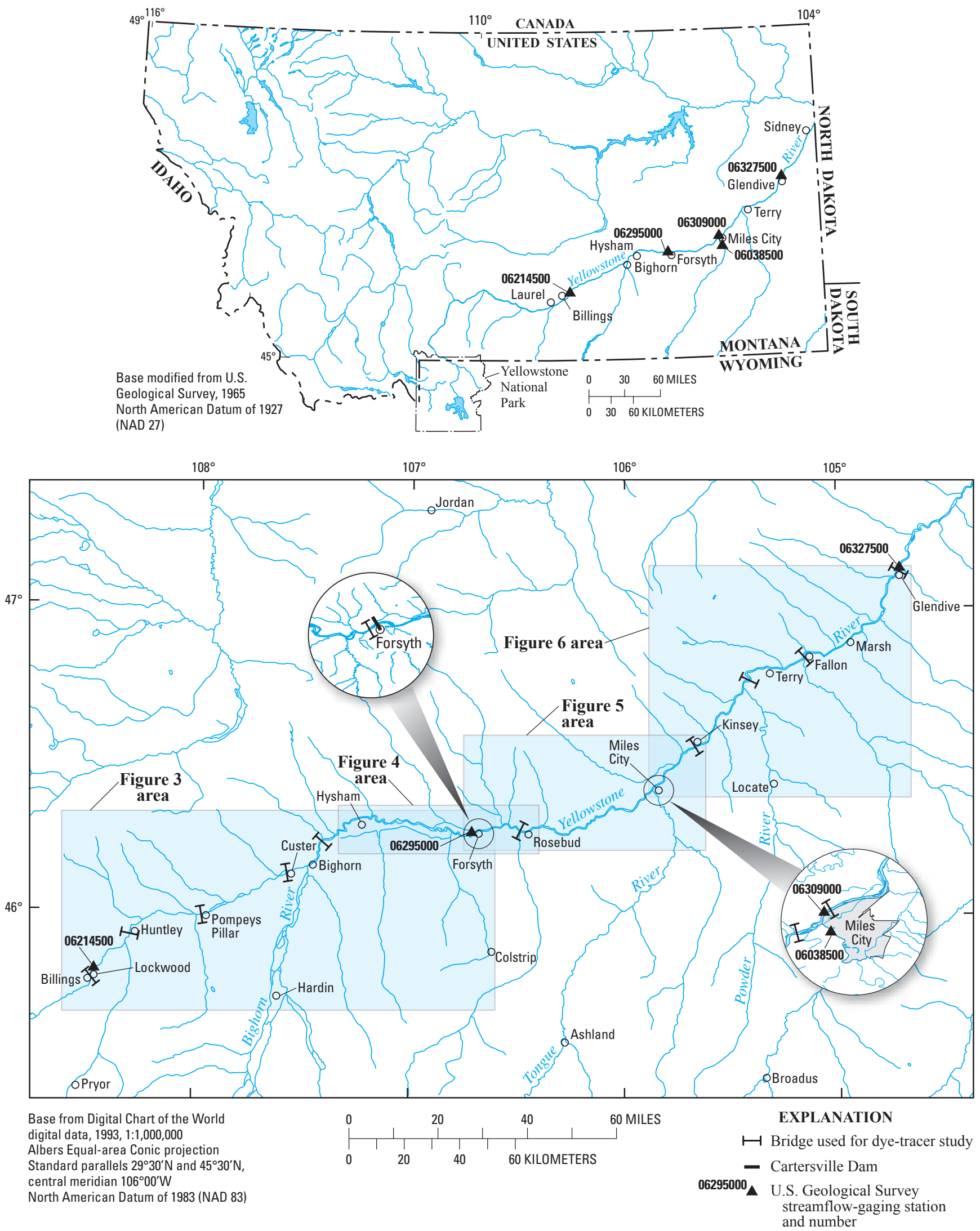

Figure 1. Locations of the study area and sites used for dye injection or measuring, Yellowstone River, Montana. 
Table 1. Injection and measurement sites along the Yellowstone River, Montana.

[River mileages from Montana Department of Natural Resources and Conservation (1976) and Google, Inc. (2008). Abbreviations: NAD 83, North American Datum of 1983; mi, miles]

\begin{tabular}{|c|c|c|c|c|c|c|}
\hline \multirow{2}{*}{ Site names } & \multicolumn{2}{|c|}{$\begin{array}{l}\text { Site location } \\
\text { (NAD 83) }\end{array}$} & \multirow{2}{*}{ Site description } & \multirow{2}{*}{$\begin{array}{c}\text { River } \\
\text { mileage } \\
(\mathrm{mi})\end{array}$} & \multirow{2}{*}{$\begin{array}{l}\text { Used for dye } \\
\text { injection }\end{array}$} & \multirow{2}{*}{$\begin{array}{l}\text { Used for dye } \\
\text { measuring }\end{array}$} \\
\hline & Latitude & Longitude & & & & \\
\hline Lockwood Bridge & $\mathrm{N} 45^{\circ} 47^{\prime} 47^{\prime \prime}$ & W $108^{\circ} 28^{\prime} 12^{\prime \prime}$ & U.S. Route 87 bridge near Lockwood & 360.6 & Yes & No. \\
\hline Huntley Bridge & $\mathrm{N} 45^{\circ} 54^{\prime} 14^{\prime \prime}$ & W $108^{\circ} 19^{\prime} 03^{\prime \prime}$ & U.S. Route 312 bridge near Huntley & 348.6 & No & Yes. \\
\hline Pompeys Bridge & $\mathrm{N} 45^{\circ} 59^{\prime} 48^{\prime \prime}$ & W $108^{\circ} 00^{\prime} 32^{\prime \prime}$ & Bundy Road bridge near Pompeys Pillar & 328.6 & No & Yes. \\
\hline Custer Bridge & $\mathrm{N} 46^{\circ} 08^{\prime} 32^{\prime \prime}$ & W $107^{\circ} 32^{\prime} 56^{\prime \prime}$ & State Route 310 bridge near Custer & 300.1 & No & Yes. \\
\hline Myers Bridge & $\mathrm{N} 46^{\circ} 15^{\prime} 16^{\prime \prime}$ & W $107^{\circ} 20^{\prime} 44^{\prime \prime}$ & State Route 311 bridge near Myers & 283.3 & Yes & Yes. \\
\hline Forsyth Bridge & $\mathrm{N} 46^{\circ} 15^{\prime} 51^{\prime \prime}$ & W $106^{\circ} 41^{\prime} 45^{\prime \prime}$ & U.S. Route 12 bridge at Forsyth & 238.8 & No & Yes. \\
\hline Cartersville Dam & $\mathrm{N} 46^{\circ} 16^{\prime} 32^{\prime \prime}$ & W $106^{\circ} 40^{\prime} 47^{\prime \prime}$ & Diversion dam at Forsyth & 237.7 & Yes & Yes. \\
\hline Rosebud Bridge & $\mathrm{N} 46^{\circ} 16^{\prime} 29^{\prime \prime}$ & W $106^{\circ} 27^{\prime} 53^{\prime \prime}$ & State Route 446 bridge near Rosebud & 224.2 & No & Yes. \\
\hline Fort Keogh Bridge & $\mathrm{N} 46^{\circ} 23^{\prime} 54^{\prime \prime}$ & W $105^{\circ} 53^{\prime} 45^{\prime \prime}$ & Fort Keogh Road bridge near Miles City & 186.2 & No & Yes. \\
\hline Miles City Bridge & $\mathrm{N} 46^{\circ} 25^{\prime} 15^{\prime \prime}$ & W $105^{\circ} 51^{\prime} 36^{\prime \prime}$ & State Route 59 bridge at Miles City & 183.7 & Yes & No. \\
\hline Kinsey Bridge & $\mathrm{N} 46^{\circ} 31^{\prime} 53^{\prime \prime}$ & W $105^{\circ} 42^{\prime} 51^{\prime \prime}$ & Kinsey Road bridge near Kinsey & 171.9 & No & Yes. \\
\hline Calypso Bridge & $\mathrm{N} 46^{\circ} 46^{\prime} 47^{\prime \prime}$ & W $105^{\circ} 24^{\prime} 40^{\prime \prime}$ & Milwaukee Road bridge near Calypso & 144.9 & No & Yes. \\
\hline Fallon Bridge & $\mathrm{N} 46^{\circ} 51^{\prime} 20^{\prime \prime}$ & W $105^{\circ} 06^{\prime} 59^{\prime \prime}$ & CB Route Road bridge near Fallon & 126.9 & No & Yes. \\
\hline Glendive Bridge & $\mathrm{N} 47^{\circ} 06^{\prime} 21^{\prime \prime}$ & W $104^{\circ} 43^{\prime} 09^{\prime \prime}$ & $\begin{array}{l}\text { West Bell Street pedestrian bridge at } \\
\text { Glendive }\end{array}$ & 94.6 & No & Yes. \\
\hline
\end{tabular}

characteristics of the stream, velocity variations, and how the dye is injected into the stream. Typically, vertical mixing throughout the water column requires the shortest distance from the point of injection. Lateral mixing across the width of the channel requires a greater distance than vertical mixing and until the dye is mixed laterally, its movement does not represent that of the total flow. Lateral mixing of the dye will occur more quickly if the dye is injected at multiple points across the channel. Longitudinal mixing or dispersion, the dispersion component of primary interest, occurs indefinitely (Kilpatrick and Wilson, 1989).

\section{General Description of Dye Tracing}

Dye-tracer concentrations measured continuously at points downstream from an instantaneous dye-injection can be plotted as a function of time to create a time-concentration curve. The time-concentration curves are the basis for determining time-of-travel and dispersion characteristics of streams. Theoretical characteristics of a time-concentration curve for a stream are shown in figure 2. This timeconcentration curve can be used to describe dye movement past a fixed measurement point located downstream from a dye injection (Kilpatrick and Wilson, 1989).
The dye concentration and movement characteristics pertinent to time-of-travel measurements are the following:

$T_{l}, \quad$ travel time of leading edge of dye plume;

$T_{p}, \quad$ travel time of peak concentration of dye plume;

$T_{c}$, travel time of centroid of dye plume;

$T_{10 p}, \quad$ travel time of trailing edge of dye plume where dye concentration is reduced to 10 percent of the peak concentration; and

$T_{t}, \quad$ travel time of trailing edge of dye plume.

The mean travel time $\left(t_{c}\right)$ for the flow along the stream line is the difference in elapsed time of the centroids of the timeconcentration curves defined upstream and downstream on the same stream line:

$$
t_{c}=T_{c(n+1)}-T_{c(n)},
$$

where $n$ is the number of the sampling site, and all other terms are as previously defined. The time required for the centroid of a dye plume to travel through a river reach $\left(t_{c}\right)$ is used to calculate the mean velocity of the centroid of the dye plume, which represents the mean streamflow velocity for the reach. 


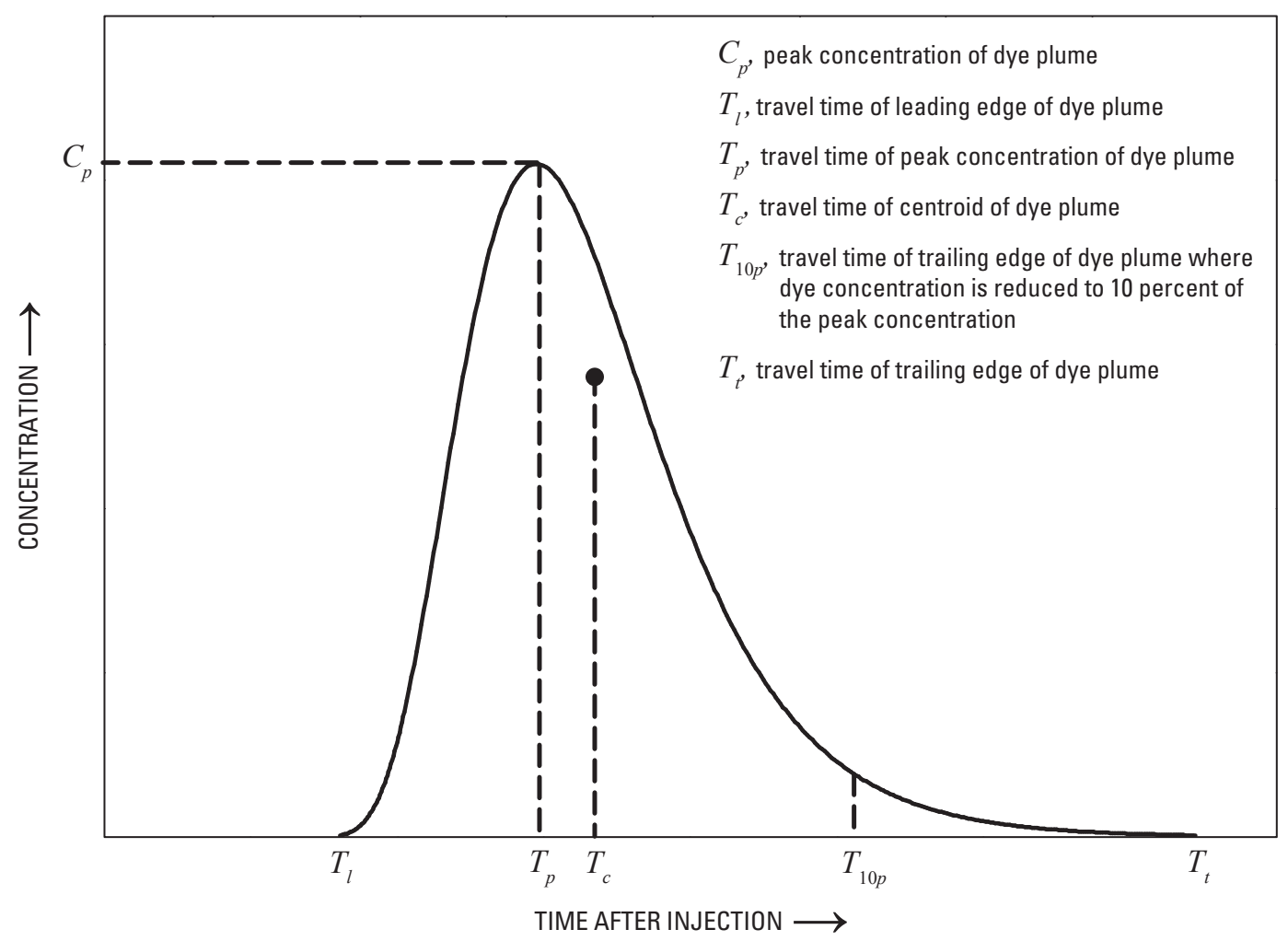

Figure 2. A typical time-concentration curve for the movement of dye past a fixed measurement point downstream from a dye injection (modified from Kilpatrick and Wilson, 1989).

The mean travel times of the leading edge $\left(t_{t}\right)$, peak concentration $\left(t_{p}\right), 10$ percent of the peak concentration $\left(t_{10 p}\right)$, and trailing edge $\left(t_{t}\right)$ along a given stream line are, respectively,

$$
\begin{gathered}
\mathrm{t}_{l}=T_{l(n+1)}-T_{l(n)}, \\
t_{p}=T_{p(n+1)}-T_{p(n)}, \\
t_{10 p}=T_{10 p(n+1)}-T_{10 p(n)} ; \text { and } \\
t_{t}=T_{t(n+1)}-T_{t(n)},
\end{gathered}
$$

where all terms are as previously defined. These travel times are used to calculate the mean velocity of the travel-time components through a river reach. These mean velocities are then used to estimate longitudinal dispersion rates and also are used for management decisions for source-water intakes when a contaminant is present in the river.

The time, $T_{d}$, necessary for the dye plume to completely pass a measurement site in a section is:

$$
T_{d}=T_{t(n)}-T_{l(n)} .
$$

The time, $T_{10 d}$, necessary for the dye plume to pass a measurement site until the concentration of the dye plume on the trailing edge is 10 percent of the peak concentration (duration) is:

$$
T_{10 d}=T_{10 p(n)}-T_{l(n)} .
$$

\section{Dye Injections}

For this study, RWT dye was injected into the Yellowstone River at four sites: Lockwood Bridge, Myers Bridge, Cartersville Dam, and Miles City Bridge. Four separate instantaneous dye injections were made to keep peak dye concentrations below $10 \mu \mathrm{g} / \mathrm{L}$ at municipal water intakes while maintaining measureable concentrations of the dye. The maximum allowable peak concentration of RWT dye at municipal water intakes was determined by the U.S. Environmental Protection Agency to be $10 \mu \mathrm{g} / \mathrm{L}$ (Office of the Federal Register, 1998). Thirteen bridges and one low-head dam were used for injecting and measuring dye. Bridges were selected for injecting and measuring because they provided the safest access to the centroid of the river. Dye that was injected at 
Travel Times, Streamflow Velocities, and Dispersion Rates in the Yellowstone River, Montana

Lockwood Bridge was measured downstream at Huntley Bridge, Pompeys Bridge, Custer Bridge, Myers Bridge, and Forsyth Bridge (fig. 3). Dye that was injected at Myers Bridge was measured downstream at Forsyth Bridge, Cartersville Dam, and Rosebud Bridge (fig. 4). Dye that was injected at Cartersville Dam was measured downstream at Rosebud Bridge, Fort Keogh Bridge, and Kinsey Bridge (fig. 5). Dye that was injected at Miles City Bridge was measured downstream at Kinsey Bridge, Calypso Bridge, Fallon Bridge, and Glendive Bridge (fig. 6).

RWT dye at 20-percent stock solution was used as the dye tracer for this time-of-travel study because it is a nearly conservative, water-soluble, nontoxic dye that can be detected at low concentrations using a fluorometer. The volume of RWT dye injected at Lockwood Bridge, Myers Bridge, Cartersville Dam, and Miles City Bridge was 68.0, 21.0, 33.0, and $51.5 \mathrm{~L}$, respectively. The resulting instantaneous concentration of dye in the Yellowstone River at each of the injection sites was $160,25,38$, and $55 \mathrm{mg} / \mathrm{L}$, respectively. Multiple lateralinjection points were used at each injection site to accelerate lateral mixing because travel times of the dye, once it is completely mixed laterally, more accurately represent mean streamflow velocity of the Yellowstone River. The distance required for complete lateral mixing (optimal mixing length, table 2) for each injection site was calculated based on flow and channel characteristics just downstream from each injection site using equation 7 from Kilpatrick and Wilson (1989). Three lateral-injection points (across the channel) were used for injections at Miles City Bridge, Cartersville Dam, and Myers Bridge. At each of these three injections sites, the total volume of dye injected was split equally and injected at points of 25,50 , and 75 percent of total streamflow measured from the left streambank to the right streambank. Similarly, four lateral-injection points were used for the injection at Lockwood Bridge because the streamflow was split equally into two channels. Thus, dye was injected at points of 40 and 60 percent of streamflow in each channel.

Until the dye is completely mixed in the lateral dimension, its movement does not represent that of the total streamflow. The dye is considered completely mixed when the time-concentration curves for laterally separate points across the stream at the same location are virtually equal. Traveltime data represent the mean travel time of a river reach only when the dye is completely laterally mixed throughout the entire river reach between measurement sites. For each of the four injections (Lockwood Bridge, Myers Bridge, Cartersville Dam, and Miles City), travel times that were calculated from the injection site to the first measurement site downstream (Huntley Bridge, Forsyth Bridge, Rosebud Bridge, and Kinsey Bridge, respectively) do not accurately represent the mean travel time of those subreaches because the dye was not completely laterally mixed for the entire subreach. Therefore, each of these subreaches were overlapped by subsequent dye injections such that representative travel times could be calculated for the entire study reach from Huntley Bridge to Glendive Bridge. Only the unmixed travel times could be measured for the subreach from Lockwood Bridge (farthest upstream injection site) to the Huntley Bridge (farthest upstream measurement site). These travel times probably are not representative of the mean streamflow travel times because the dye was not completely laterally mixed for the entire subreach. For the purpose of this report, calculated velocities for subreaches where the dye is completely laterally mixed will be referred to as completely mixed velocities. In contrast, calculated velocities for subreaches where the dye is not completely laterally mixed will be referred to as unmixed velocities.

\section{Fluorometric Measurements}

At each measurement site downstream from a dyeinjection site, a Self-Contained Underwater Fluorescence Apparatus (SCUFA) was used to measure the fluorescence of the dye (Turner Designs, 2004). The SCUFA fluorometer converts the measured fluorescence of the dye to a direct concentration when it is calibrated to known dye concentrations. Prior to each of the dye injections, the SCUFAs were calibrated against known dye concentrations of $0 \mu \mathrm{g} / \mathrm{L}, 5 \mu \mathrm{g} / \mathrm{L}$, $15 \mu \mathrm{g} / \mathrm{L}$, and $25 \mu \mathrm{g} / \mathrm{L}$ depending on the peak dye concentration expected at the measurement site. The SCUFAs were deployed from bridges at each measurement site and were suspended in the water column in the centroid of flow. The centroid of flow was determined by making an instantaneous streamflow measurement with an acoustic Doppler current profiler (ADCP) at the measurement site. Instantaneous streamflow measurements were made in accordance with the procedures described by Oberg and others (2005). At measurement sites where streamflow measurements could not be made, streamflow was estimated from upstream and downstream streamflow measurements.

SCUFAs were deployed at each measurement site to record the dye concentrations from the arrival to the trailing edge at 10 percent of the peak concentration of the dye plume. The SCUFAs were programmed to collect a reading every 30 seconds for most sites. For two sites, the collection rate was increased to every 10 seconds in an attempt to record more data before algae accumulation affected the measurements. Because of time constraints, the concentration of the trailing edge was measured until it decreased to less than 10 percent of the peak concentration.

Fluorescence measurements are commonly affected by temperature and turbidity. The SCUFA is ideal for RWT dye studies because the instruments are temperature compensated and also measure turbidity. Temperature compensation eliminates substantial errors that can arise from fluctuating water temperatures. Although the SCUFA fluorometer is very effective at limiting interference from turbidity, highly turbid waters may still affect measurements. Turbidity measurements and RWT dye concentrations were recorded simultaneously to evaluate turbidity interference (Turner Designs, 2004). Turbidity measurements can be affected by stream turbulence, which was experienced during this study when algal blooms along 


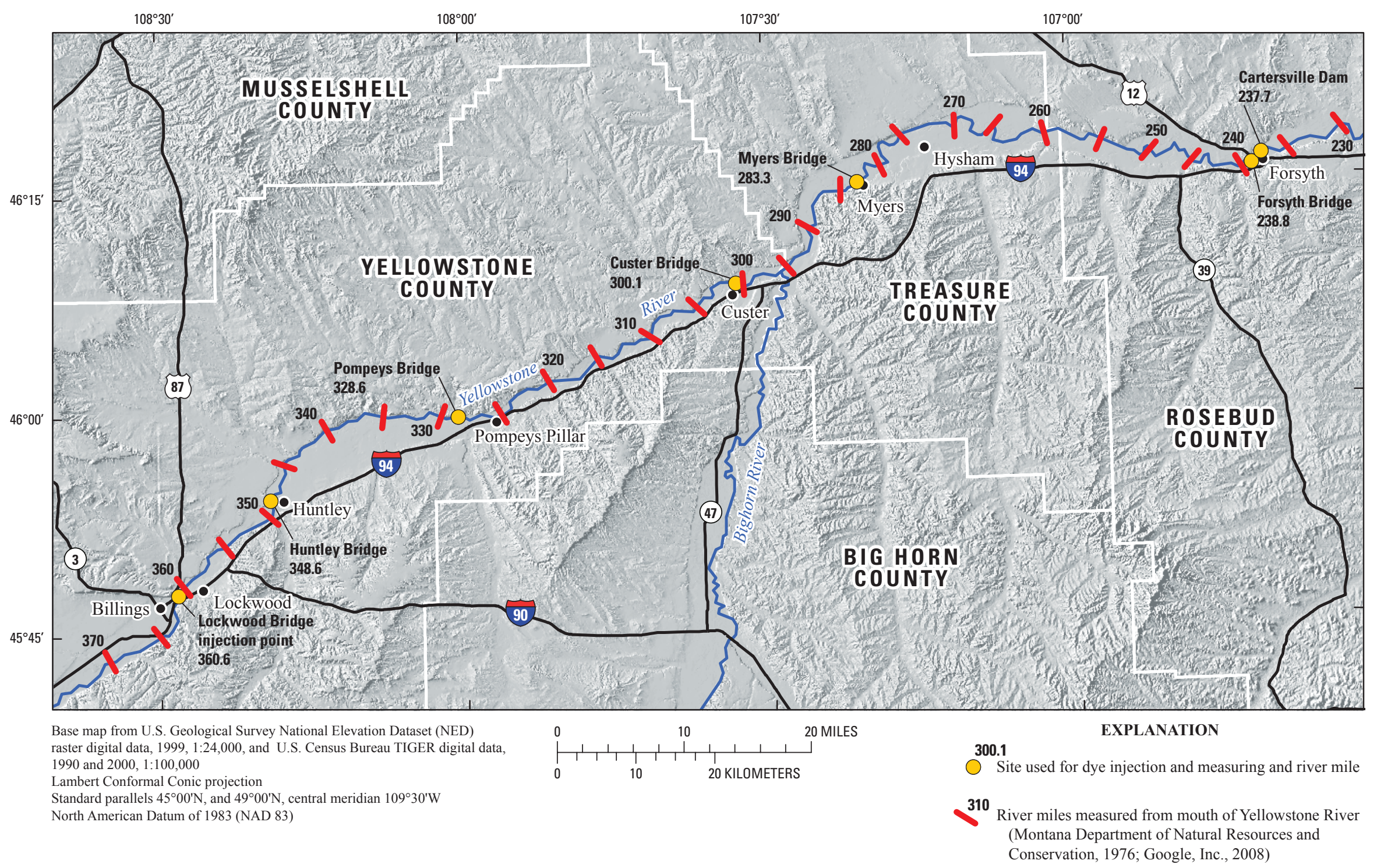

Figure 3. Location of subreach for dye injection at Lockwood Bridge, Montana. 


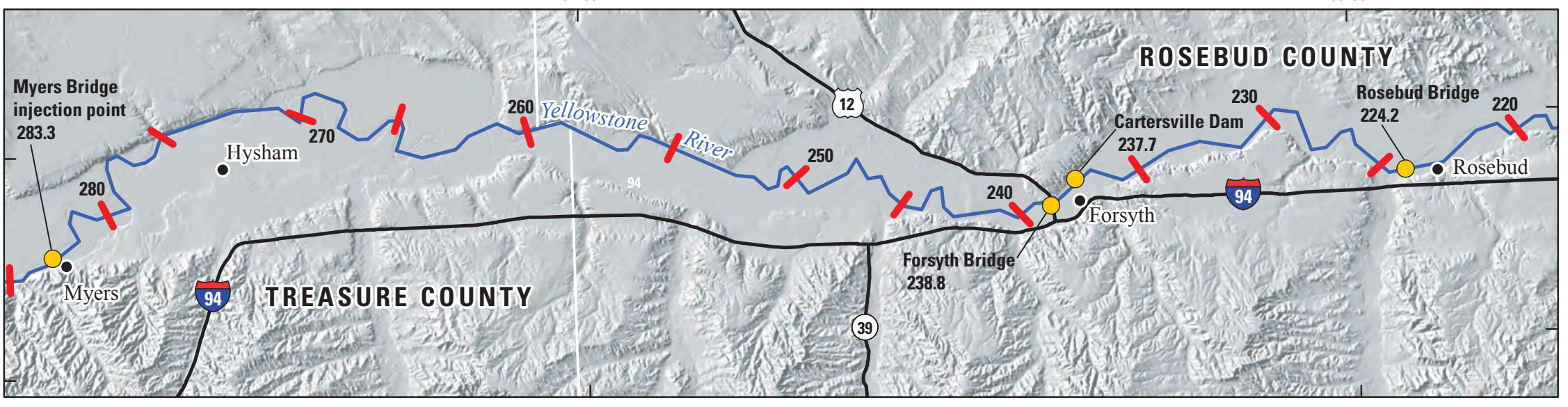

$46^{\circ} 12^{\prime}$

Figure 4. Location of subreach for dye injection at Myers Bridge, Montana.

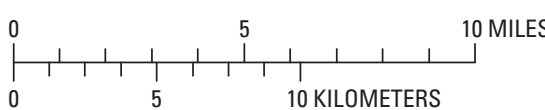

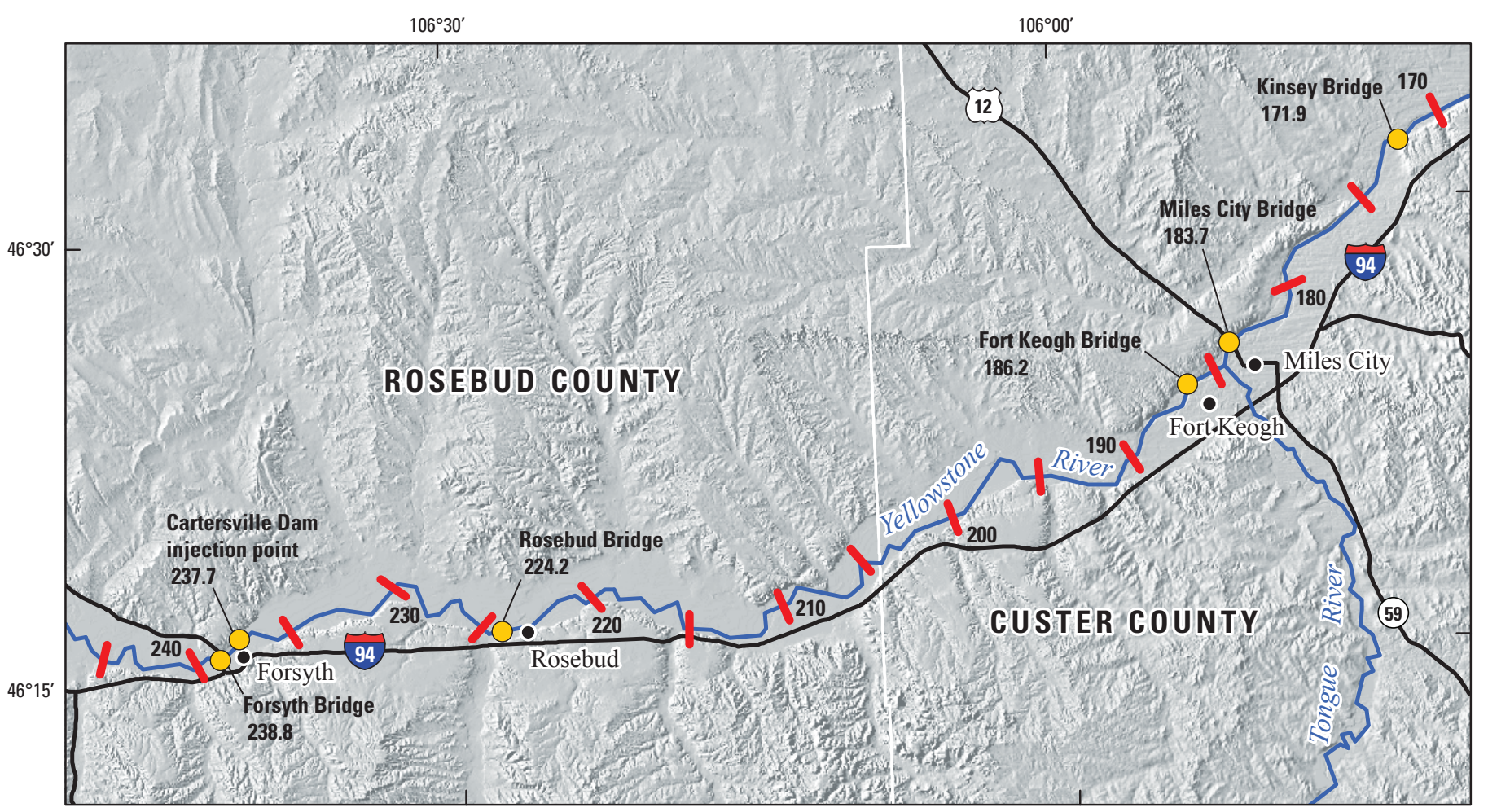

Base maps from U.S. Geological Survey National Elevation Dataset (NED) raster digital data, 1999 $1.24,000$, and U.S. Census Bureau TIGER digital

data, 1990 and $2000,1: 100,000$

Lambert Conformal Conic projection

central meridian $109^{\circ} 30^{\circ} \mathrm{N}$

North American Datum of 1983 (NAD83)

\section{EXPLANATION}

Site used for dye injection and measuring and river mile

180 River miles measured from mouth of Yellowstone River (Montana Department of Natural Resources and Conservation, 1976; Google, Inc., 2008)

Figure 5. Location of subreach for dye injection at Cartersville Dam, Montana. 


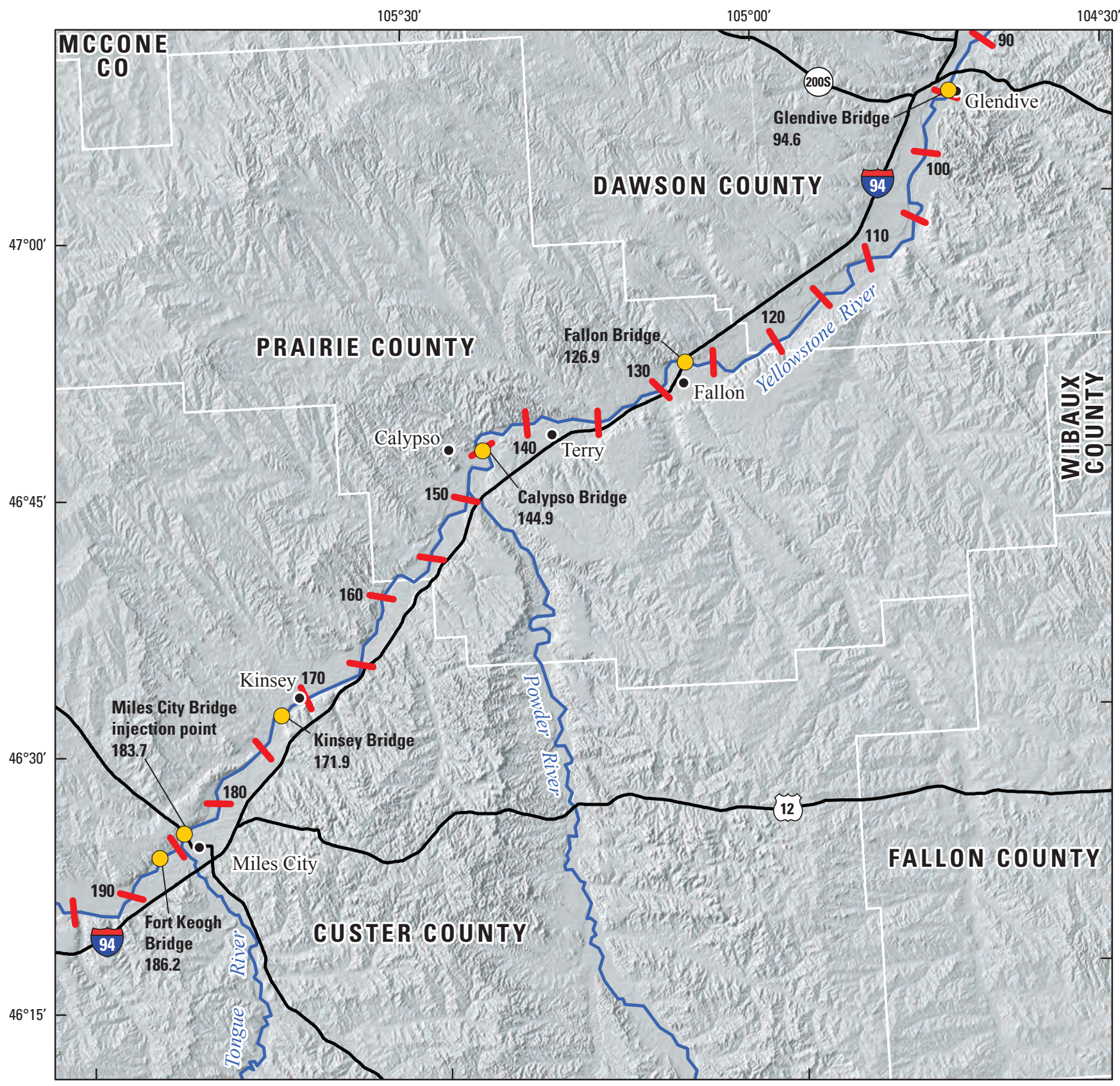

\subsection{EXPLANATION}

Site used for dye injection and measuring and river mile

90 River miles measured from mouth of

Yellowstone River (Montana Department of Natural Resources and Conservation, 1976; Google, Inc., 2008)

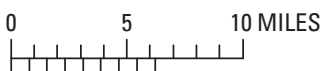 \\ $\begin{array}{lll}0 & 5 & 10 \text { KILOMETERS }\end{array}$}

Base map from U.S. Geological Survey National

Elevation Dataset (NED) raster digital data, 1999

1:24,000, and U.S. Census Bureau TIGER digital data,

1990 and 2000, 1:100,000

Lambert Conformal Conic projection

Standard parallels $45^{\circ} 00^{\prime} \mathrm{N}$, and $49^{\circ} 00^{\prime} \mathrm{N}$

central meridian $109^{\circ} 30^{\prime} \mathrm{W}$

North American Datum of 1983 (NAD 83)

Figure 6. Location of subreach for dye injection at Miles City Bridge, Montana. 
Table 2. Optimal mixing length for each injection site along the Yellowstone River, Montana.

[Time reported in military time as hours and minutes. Abbreviations: $\mathrm{ft}^{3} / \mathrm{s}$, cubic feet per second; mi, miles]

\begin{tabular}{llcccc}
\hline \multicolumn{1}{c}{ Injection site } & Date of injection & Time of injection & $\begin{array}{c}\text { Instantaneous } \\
\text { streamflow } \\
\left(\mathbf{f t}^{3} \mathbf{s}\right)\end{array}$ & $\begin{array}{c}\text { Number of } \\
\text { lateral injection } \\
\text { points }\end{array}$ & $\begin{array}{c}\text { Optimal mixing } \\
\text { length } \\
(\mathbf{m i})\end{array}$ \\
\hline Lockwood Bridge & October 6, 2008 & 1410 & 3,500 & 4 & 1.9 \\
Myers Bridge & September 29, 2008 & 1700 & 6,750 & 3 & 4.1 \\
Cartersville Dam & September 26, 2008 & 1000 & 16,860 & 3 & 4.1 \\
Miles City Bridge & September 23, 2008 & 1003 & 7,420 & 3 & 6.5 \\
\hline
\end{tabular}

${ }^{1}$ Instantaneous streamflow estimated from upstream and downstream streamflow measurements where discharge could not be measured.

the Yellowstone River caused buildup of algae on the deployed SCUFAs. When algae accumulated on the SCUFAs, the turbulence increased, which caused spikes in turbidity and fluorescence. To reduce the interference of algae on the fluorescence readings, the SCUFAs were frequently cleaned.

In addition to deploying the SCUFAs, grab samples also were collected at measurement sites at 15-, 30-, 45-, $60-$, or 90-minute intervals depending on the expected timeof-passage of the dye. These grab samples were collected at a single point near the centroid of flow where water was assumed to be well mixed.

\section{Development of Time-Concentration Curves}

SCUFA data (appendix 1) for each site were reviewed, and outliers from the time-concentration curve were removed from the data set. Outliers were defined as data values with an associated spike in turbidity or as values that substantially deviated from the time-concentration curve. Outliers were selected using best professional judgement. After outliers were removed from the data set, all the data were shifted up or down such that concentration values preceding the arrival of the dye (that is, background values) were zero (appendix 2). The SCUFA data may have background concentrations different than zero because the SCUFA measures fluorescence and converts this value to a concentration based on the calibration performed in the field. When background fluorescence values of the measurement site are different than the calibration standard of $0 \mu \mathrm{g} / \mathrm{L}$, the calculated concentration of dye may be greater than or less than zero. Raw SCUFA data and adjusted SCUFA data collected at Pompeys Bridge are presented in figure 7 as an example of the adjustments made to the data set.

The discrete grab samples were analyzed with a bench fluorometer for RWT dye concentrations by the USGS Montana Water Science Center, Helena, Montana, and the resulting data were used to develop time-concentration curves. A Turner Designs Model 10 bench fluorometer was calibrated using standards with concentrations of $0 \mu \mathrm{g} / \mathrm{L}$ and $5 \mu \mathrm{g} / \mathrm{L}$ of RWT dye created in the laboratory of the Montana Water
Science Center. RWT dye standards with concentrations of $0.1 \mu \mathrm{g} / \mathrm{L}, 0.5 \mu \mathrm{g} / \mathrm{L}$, and $15 \mu \mathrm{g} / \mathrm{L}$ were used to verify the calibration of the fluorometer. The discrete samples were analyzed at a temperature of $20^{\circ} \mathrm{C}$. Data from the samples are presented in appendix 3.

Time-concentration curves were developed by fitting smooth curves to the SCUFA and discrete sample data (Kilpatrick and Wilson, 1989). Smooth curves were fit to the data by using a three-parameter log-normal equation. The three-parameter log-normal equation, parameters, and data for these curves are presented in appendix 4. In instances where the SCUFA data and discrete data were substantially different, the three-parameter log-normal curves were adjusted to fit the discrete data rather than the SCUFA data because the SCUFA data were affected by field conditions that were eliminated when analyzing the discrete data. The final time-concentration curves fit to the SCUFA and discrete data (for example Forsyth Bridge, fig. 8) were then used to determine the travel times for the arrival of the leading edge, peak concentration, centroid, trailing edge at 10 percent of the peak concentration, and the trailing edge of the plume for each measurement site. Timeconcentration curves for each of the four dye injections are shown in figures 9-12.

\section{Travel Times, Streamflow Velocities, and Dispersion Rates in the Yellowstone River}

The travel times, streamflow velocities, and dispersion rates of the subreaches were calculated by using the timeconcentration curves developed from data collected at the measurement sites. Mean velocities between measurement sites were calculated for the leading edge, peak concentration, centroid, and trailing edge at 10 percent of the peak concentration for each subreach (table 3 ). The mean velocity for the centroid of the dye plume most accurately represents the mean streamflow velocity of the river, whereas the mean velocities 


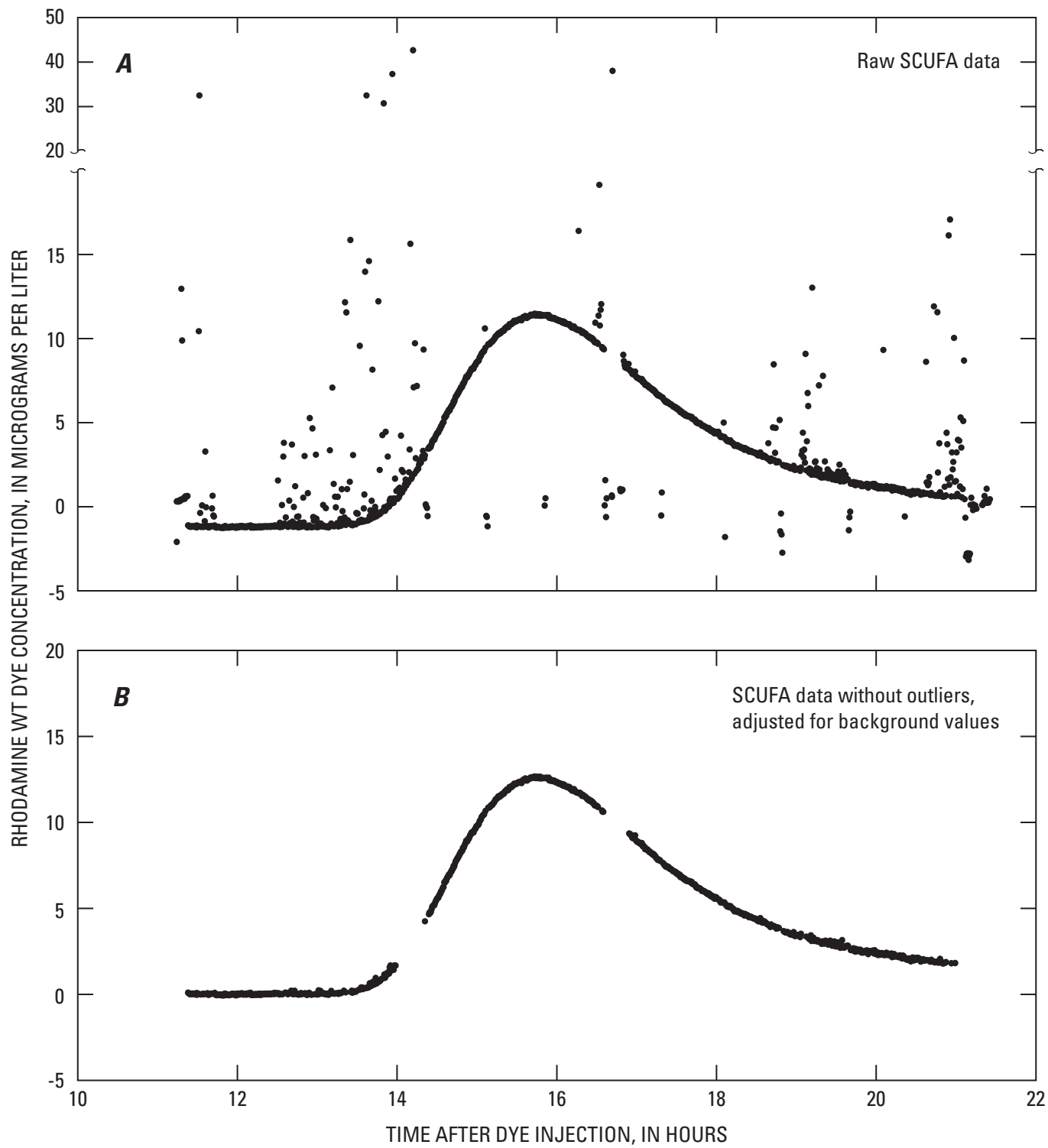

Figure 7. Concentration of Rhodamine WT dye at Pompeys Bridge, Montana. A, Raw data from SelfContained Underwater Fluorescence Apparatus (SCUFA); $B$, Adjusted SCUFA data.

of the other dye plume components typically are used for emergency response to contaminants spilled into the river.

As mentioned in the section "Dye Injections," travel-time data and mean streamflow velocities between the dye-injection site and first measurement site downstream do not accurately represent the mean streamflow velocity because of incomplete lateral mixing. Similarly, when large tributaries join the Yellowstone River, the dye will not be completely mixed laterally across the channel below the confluence and therefore the mean velocity of the dye may not accurately represent the mean velocity of the streamflow until the dye is completely laterally mixed. The Bighorn River joins the Yellowstone River within the study area between Custer Bridge and Myers Bridge at river mile 295.3, which, during this study, contributed approximately 42 percent of the streamflow $\left(2,890 \mathrm{ft}^{3} / \mathrm{s}\right.$ measured at mouth of Bighorn River, October 7, 2008). Calculated velocities of the dye plume at Myers Bridge might have been affected by incomplete lateral mixing of the Bighorn River with the Yellowstone River.

Completely mixed velocities (calculated velocities for subreaches where the dye was completely laterally mixed for the entire subreach) for the centroid of the dye plume most accurately represents the mean streamflow velocities of the river. The completely mixed velocities of the centroid (table 3 ) ranged from $1.83 \mathrm{ft} / \mathrm{s}$ for the subreach upstream from Cartersville Dam to $3.18 \mathrm{ft} / \mathrm{s}$ for the subreach upstream from Calypso Bridge. Excluding the short subreach affected by backwater upstream from Cartersville Dam, the mean of the completely 


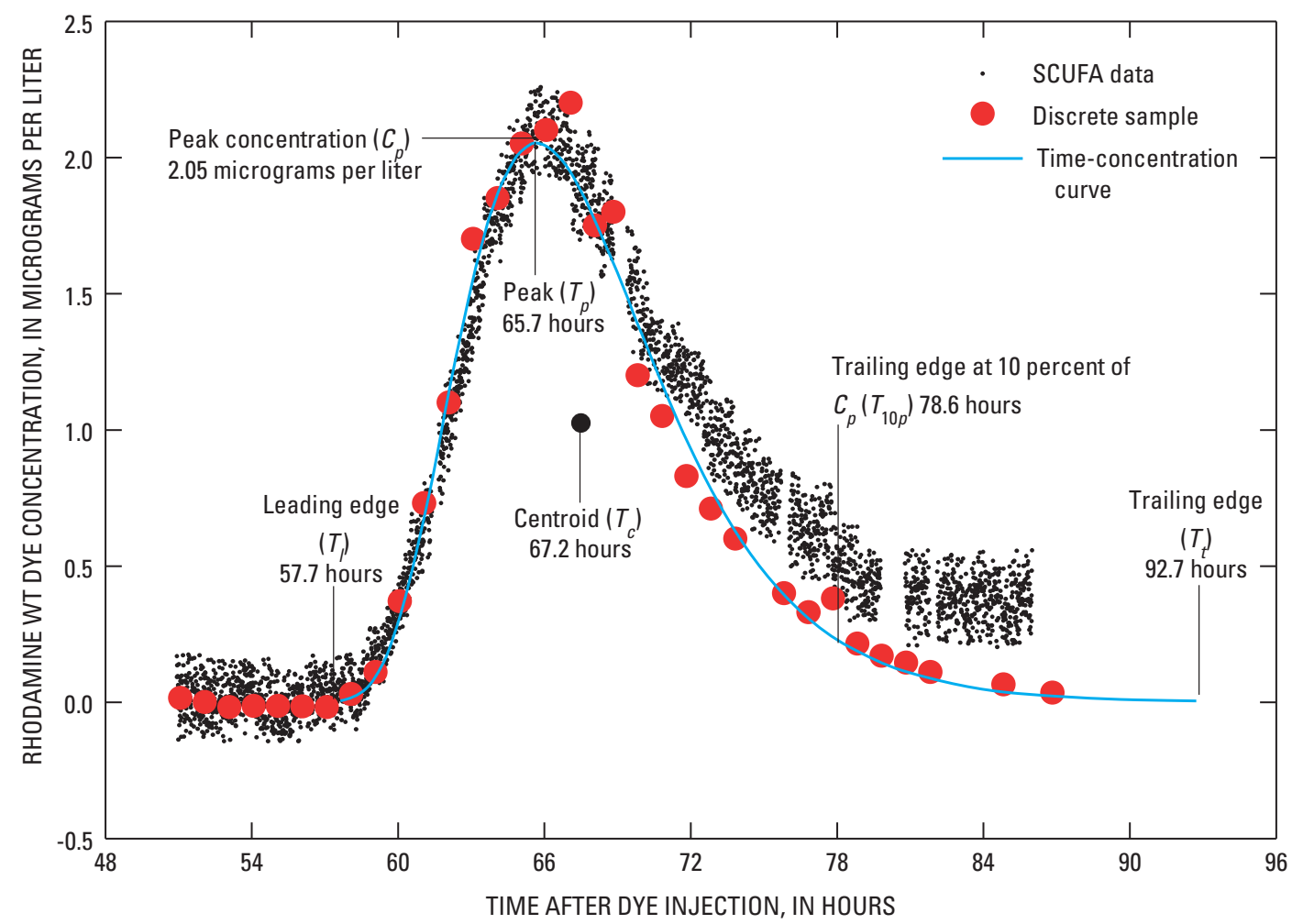

Figure 8. Rhodamine WT dye time-concentration curve fit to data from the discrete samples collected at Forsyth Bridge after September 29 dye injection at Lockwood Bridge, Montana.

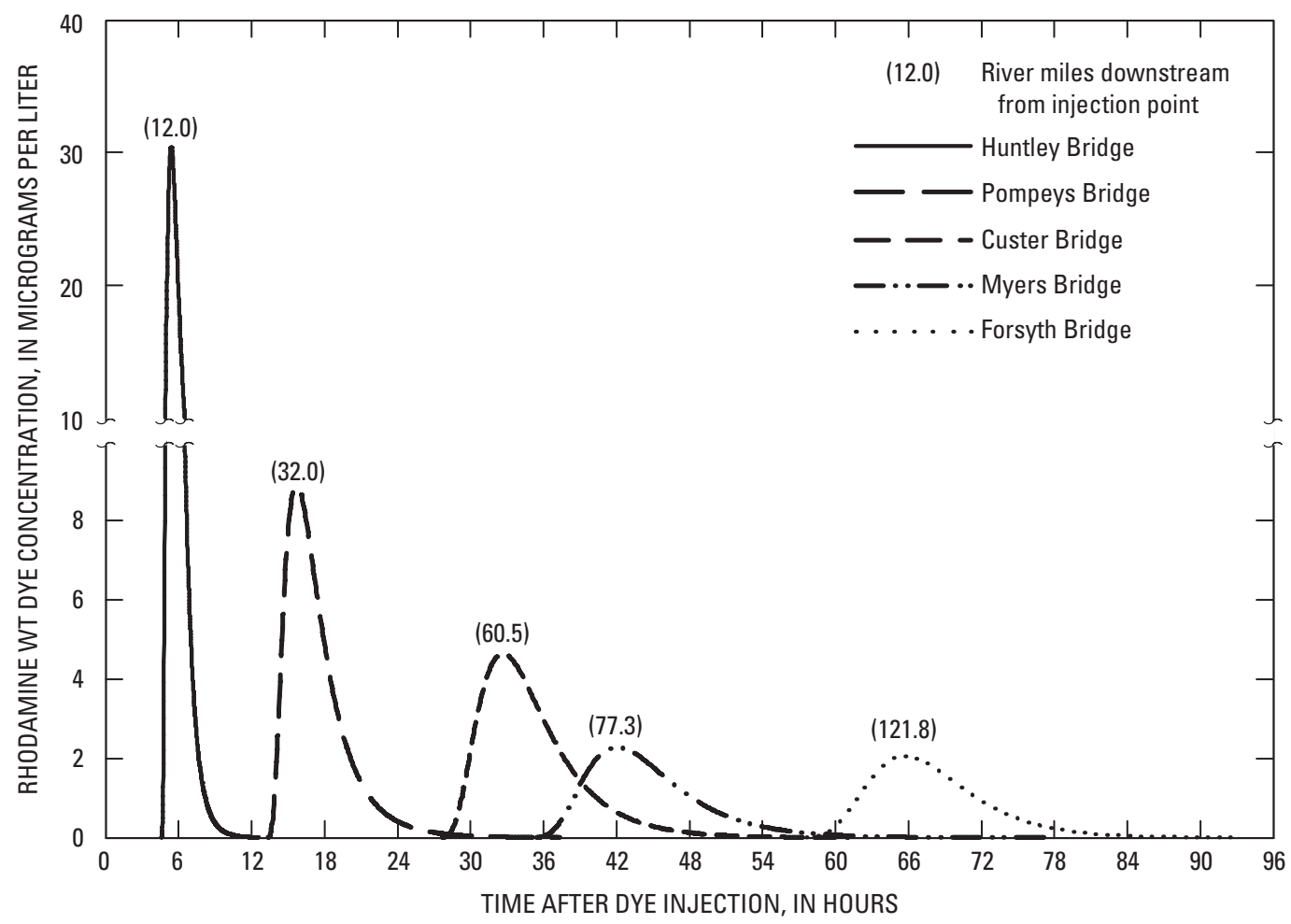

Figure 9. Time-concentration curves for Rhodamine WT dye injected at Lockwood Bridge, Montana. 


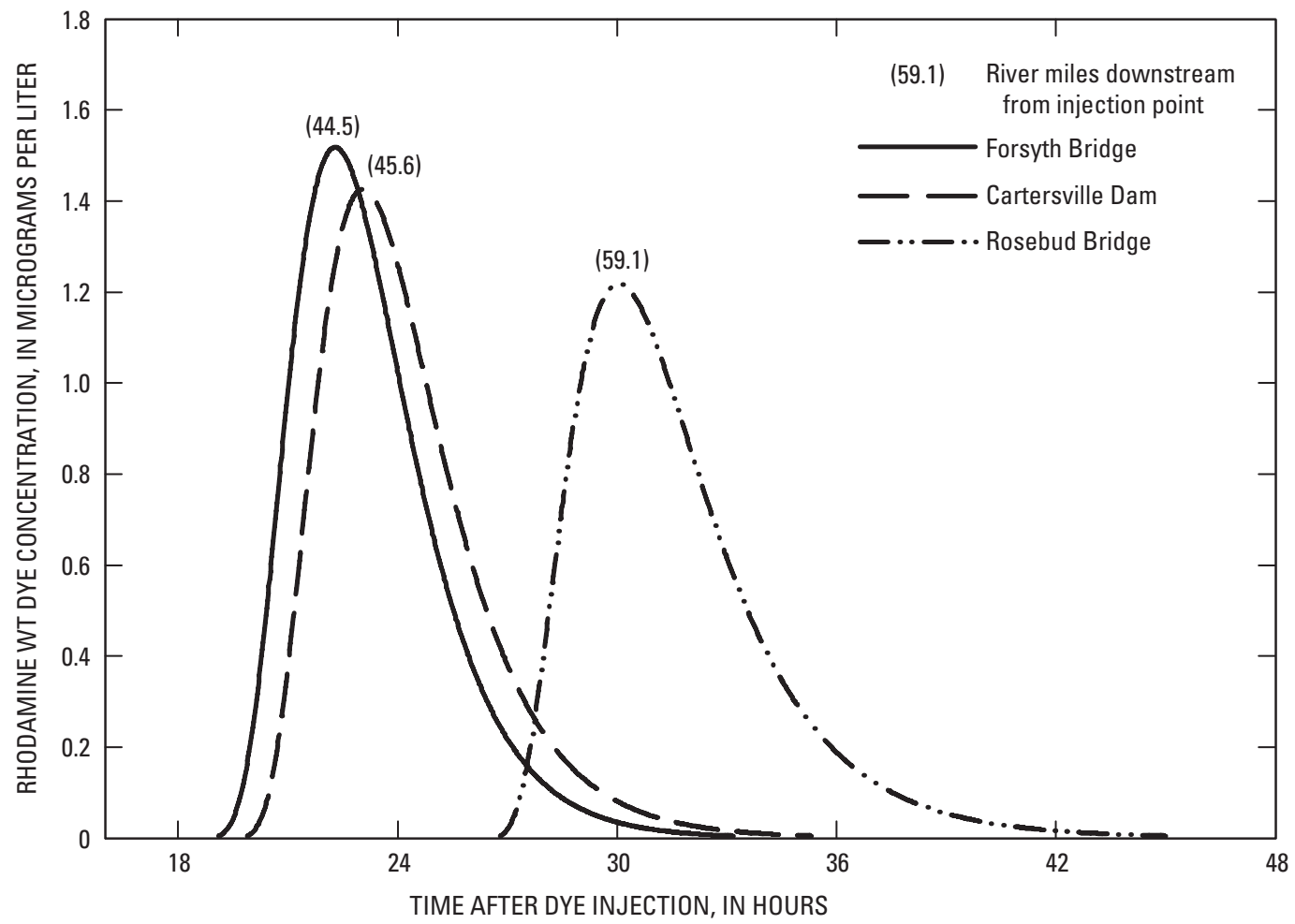

Figure 10. Time-concentration curves for Rhodamine WT dye injected at Myers Bridge, Montana.

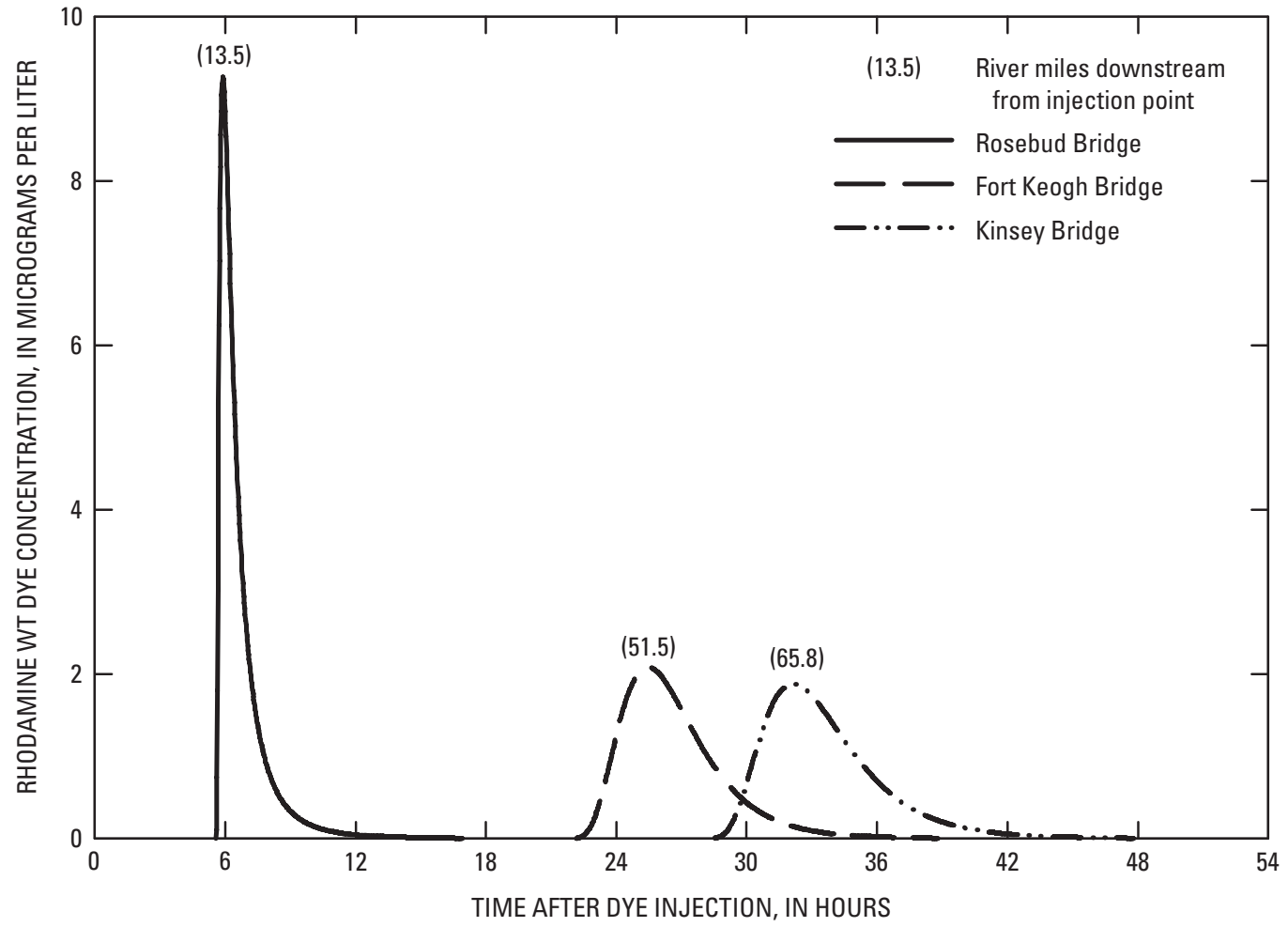

Figure 11. Time-concentration curves for Rhodamine WT dye injected at Cartersville Dam, Montana. 


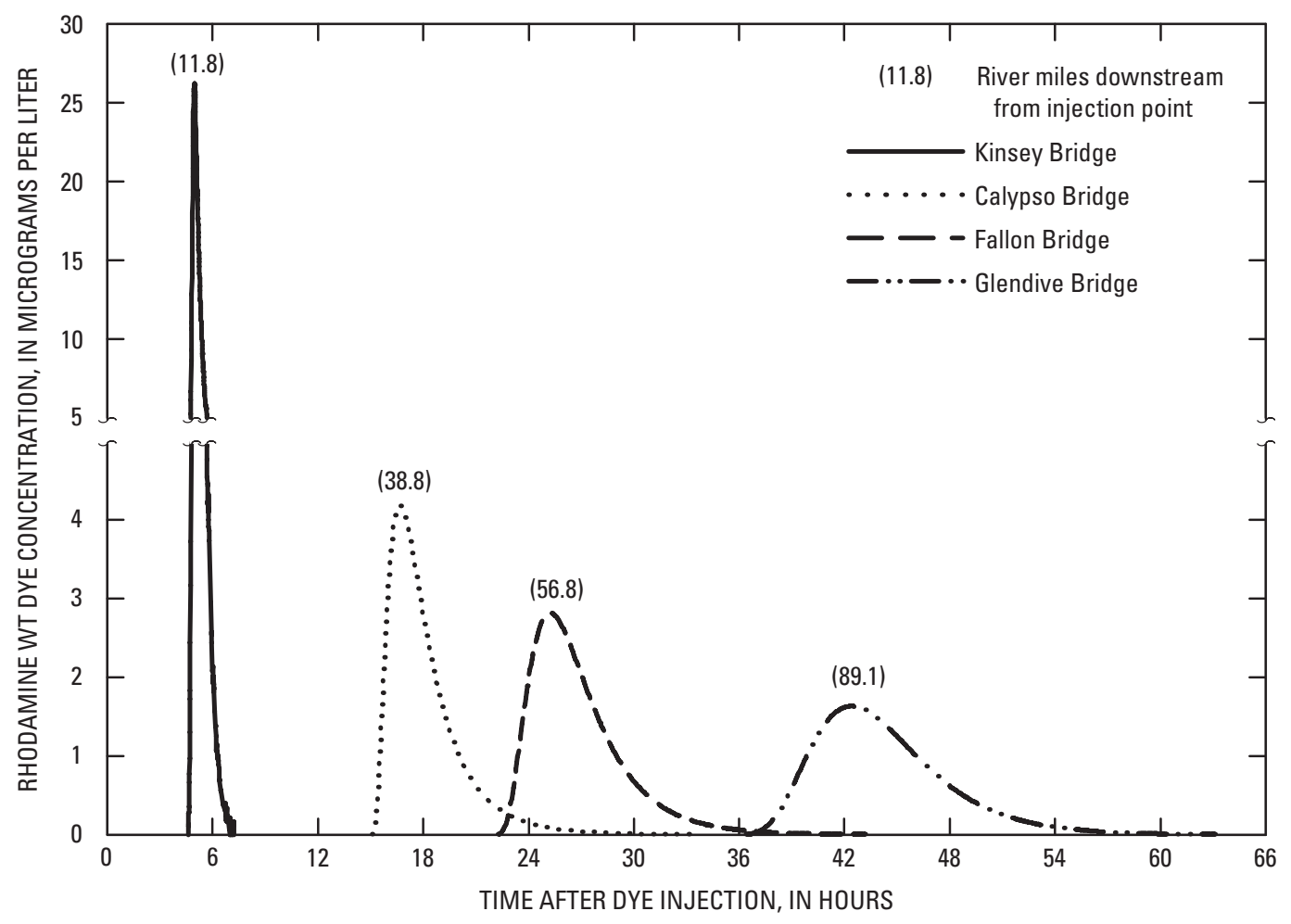

Figure 12. Time-concentration curves for Rhodamine WT dye injected at Miles City Bridge, Montana.

mixed centroid velocities for the entire study reach was $2.80 \mathrm{ft} / \mathrm{s}$, with a standard deviation of $0.24 \mathrm{ft} / \mathrm{s}$, for the streamflow conditions during this study. The fastest mean streamflow velocities generally occurred downstream from Fort Keogh Bridge, near Miles City. The slowest mean streamflow velocities generally occurred upstream from Fort Keogh Bridge.

Completely mixed velocities (calculated velocities for subreaches where the dye was completely laterally mixed for the entire subreach) for other points on the time-concentration curve typically are used by water resource managers for emergency reponse to contaminant spills into the river. The velocities of the leading edge, peak concentration, and trailing edge at 10 percent of the dye plume provide water resource managers information on when and for how long to stop withdrawals from the Yellowstone River for municipal supply. The completely mixed velocities of the leading edge of the dye plume ranged from $2.07 \mathrm{ft} / \mathrm{s}$ for the subreach upstream from Cartersville Dam to $3.77 \mathrm{ft} / \mathrm{s}$ for the subreach upstream from Calypso Bridge. Excluding the short subreach affected by backwater upstream from Cartersville Dam, the mean of the completely mixed velocities of the leading edge for the entire study reach was $3.27 \mathrm{ft} / \mathrm{s}$ with a standard deviation of $0.31 \mathrm{ft} / \mathrm{s}$. The completely mixed velocities of the peak concentration of the dye plume ranged from $2.10 \mathrm{ft} / \mathrm{s}$ for the subreach upstream from Cartersville Dam to $3.39 \mathrm{ft} / \mathrm{s}$ for the subreach upstream from Calypso Bridge. Excluding the short subreach affected by backwater upstream from Cartersville Dam, the mean of the completely mixed velocities of the peak concentration for the entire study reach was $2.88 \mathrm{ft} / \mathrm{s}$ with a standard deviation of $0.27 \mathrm{ft} / \mathrm{s}$. The completely mixed velocities of the trailing edge at 10 percent of the peak concentration of the dye plume ranged from $1.21 \mathrm{ft} / \mathrm{s}$ for the subreach upstream from Cartersville Dam to $2.74 \mathrm{ft} / \mathrm{s}$ for the subreach upstream from Forsyth Bridge. Excluding the short subreach affected by backwater upstream from Cartersville Dam, the mean of the completely mixed velocities of the trailing edge at 10 percent of the peak concentration for the entire study reach was $2.37 \mathrm{ft} / \mathrm{s}$ with a standard deviation of $0.27 \mathrm{ft} / \mathrm{s}$.

Completely mixed velocities of the leading edge and peak concentration of the dye plume averaged 16.8 and 2.9 (respectively) percent faster than the completely mixed velocities of the centroid of the dye plume. Completely mixed velocities of the trailing edge at 10 percent of the peak concentration averaged 15.4 percent slower than the velocities of the centoid of the dye.

Longitudinal dispersion of the dye plume, having no boundaries, continues indefinitely and is the dispersion component of primary interest in dye-tracer studies (Kilpatrick and Wilson, 1989). Longitudinal dispersion occurs when the leading edge of a dye plume travels in the downstream direction faster than the trailing edge of the dye plume. The longitudinal dispersion rate (table 4) was estimated for 


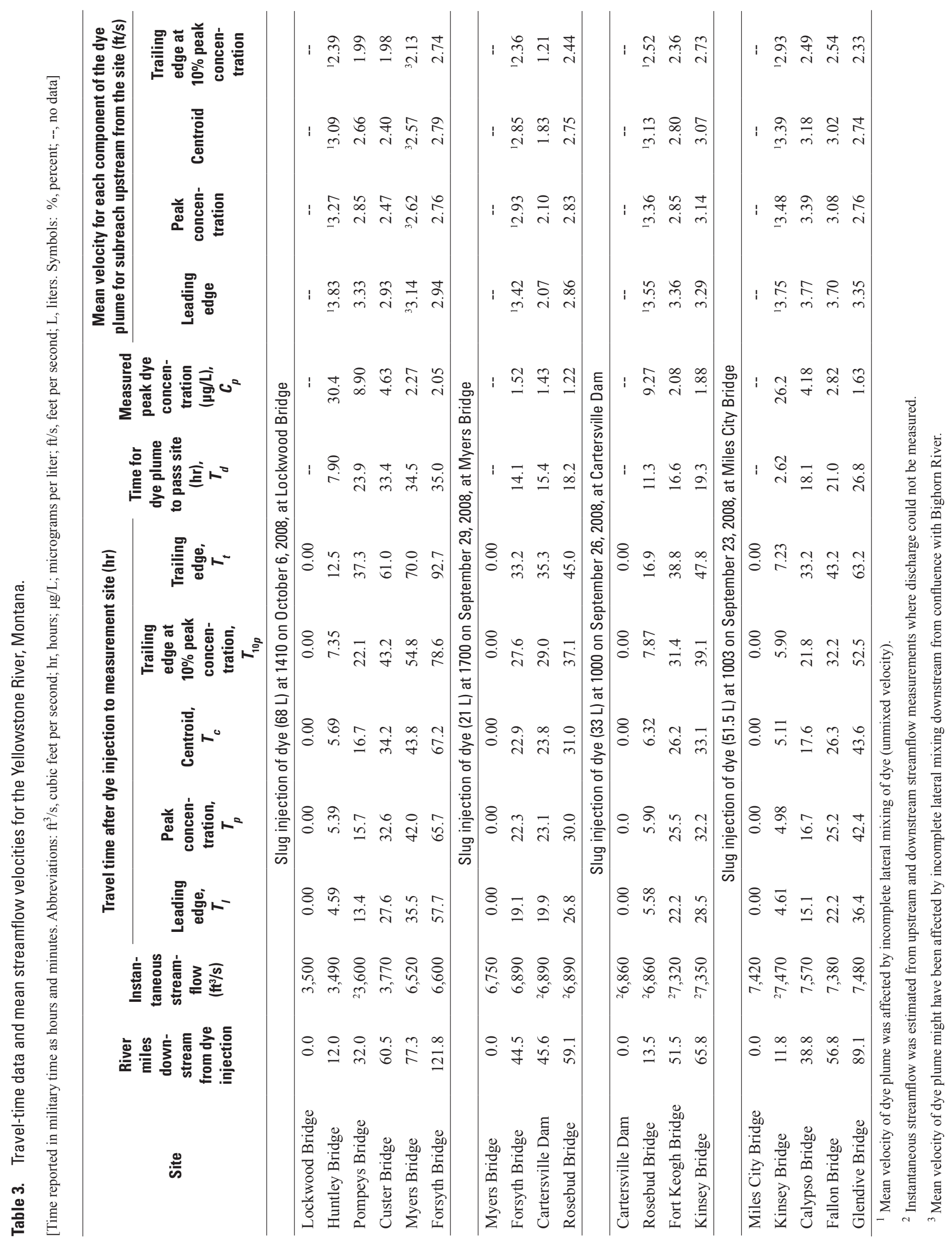


subreaches by subtracting the velocity of the trailing edge of the dye plume from the velocity of the leading edge of the dye plume. Because longitudinal dispersion continues indefinitely, the trailing edge of the dye plume was estimated from the three-parameter log-normal curves that were fit to the travel time data collected during this study (figs. 8-12). The threeparameter log-normal curves fit may not accurately represent when the trailing edge of the dye plume passes a measurement point, which may affect the estimated dispersion rates in table 4.

Longitudinal dispersion rates are dependant on the stream characteristics of the reach. Some stream characteristics that affect longitudinal dispersion rates are streamflow, the presence of split channels and pools, and the sinuosity of the river. Estimated longitudinal dispersion rates of the dye plume for this study ranged from $0.06 \mathrm{ft} / \mathrm{s}$ for the subreach upstream from Forsyth Bridge to $2.25 \mathrm{ft} / \mathrm{s}$ for the subreach upstream from Calyspo Bridge (table 4) for subreaches where the dye was completely laterally mixed.

Kilpatrick and Wilson (1989) found the time, $T_{10 d}$, necessary for the dye plume to pass a sampling point until the concentration of the dye plume on the trailing edge is 10 percent of the peak concentration (duration) can be estimated from the travel time of the peak concentration. A relation was determined between the travel time of the peak concentration and duration using data from this study for reaches where the dye was completely laterally mixed (fig. 13). This relation can be used to estimate when the receding concentration of a potential contaminant reaches

Table 4. Longitudinal dispersion rates for the Yellowstone River, Montana.

[Abbreviation: $\mathrm{ft} / \mathrm{s}$, feet per second]

\begin{tabular}{lc}
\hline \multicolumn{1}{c}{ Site } & $\begin{array}{c}\text { Longitudinal dispersion rate for subreach } \\
\text { upstream from the site (ft/s) }\end{array}$ \\
\hline Huntley Bridge & $1,22.43$ \\
Pompeys Bridge & 22.15 \\
Custer Bridge & ${ }^{2} 1.18$ \\
Myers Bridge & 2.38 \\
Forsyth Bridge & 2.06 \\
Cartersville Dam & 21.25 \\
Rosebud Bridge & 2.83 \\
Fort Keogh Bridge & 2.81 \\
Kinsey Bridge & 21.00 \\
Calypso Bridge & 22.25 \\
Fallon Bridge & 21.08 \\
Glendive Bridge & 2.97 \\
\hline
\end{tabular}

\footnotetext{
${ }^{1}$ Longitudinal dispersion rate of dye plume was affected by incomplete lateral mixing of dye.

${ }^{2}$ Velocity of the trailing edge of the dye plume was determined from fitting a three-parameter log-normal curve to the travel-time data.
}

10 percent of its peak concentration for accidental contaminant spills into the Yellowstone River. The relation between travel time of the peak concentration and duration determined from this study closely resembles the relation determined by Kilpatrick and Wilson (1989); however, the relation developed for this study may be affected by changes in streamflow in the Yellowstone River.

\section{Evaluation of the Transport-Model Estimates}

Data from this dye-tracer study were used to evaluate velocity and concentration estimates from the transport model developed by McCarthy (2006). The transport model uses equations developed by Jobson (1999) based on data from numerous dye-tracer studies conducted throughout the United States. The model estimates travel times based on estimates of both the most probable velocity and the maximum probable velocity. Estimates of the most probable velocity and the maximum probable velocity were derived by Jobson based on measured velocities from previous dye-tracer studies.

Travel-time data and completely mixed velocities (calculated velocites for subreaches where the dye was completely laterally mixed for the entire subreach) calculated for this study were compared with estimated travel-time data and streamflow velocities from the model. Figure 14 shows the difference between the estimated and calculated velocities for the leading edge, peak concentration, and trailing edge at 10 percent of the peak concentration. Comparison of the estimated and calculated velocities for the study reach (fig. 14) indicate that the transport model estimates the velocities of the Yellowstone River between Huntley Bridge and Glendive Bridge with reasonable accuracy. However, differences between estimated and measured velocities are evident.

The transport model uses several variables to estimate streamflow velocity, one of which is the stream slope. The slope used in the transport model (McCarthy, 2006) was an average slope for long reaches of the Yellowstone River. For example, the transport model uses an average slope (about $4.7 \mathrm{ft} / \mathrm{mi}$ ) for the subreach between Lockwood and the confluence with the Bighorn River even though the stream slope varies from $7.1 \mathrm{ft} / \mathrm{mi}$ at the upstream end of this subreach to $4.1 \mathrm{ft} / \mathrm{mi}$ at the downstream end of this subreach. The variability of the stream slope in the subreach from Lockwood Bridge to Forsyth Bridge would partly account for the some of the calculated velocities being faster than the maximum probable velocities in the upper end of this subreach and some of the calculated velocities being slower than the most probable velocities at the lower end of this subreach (fig. 14). Similarly, the transport model uses average stream slopes between the following sites: confluence of the Bighorn River and Forsyth Bridge, Forsyth Bridge and Miles City Bridge, Miles City Bridge and confluence of the Powder River, confluence of the Powder River and Glendive Bridge. The variability of the stream slope in these reaches would partly account for differences between estimated velocities and calculated velocities 


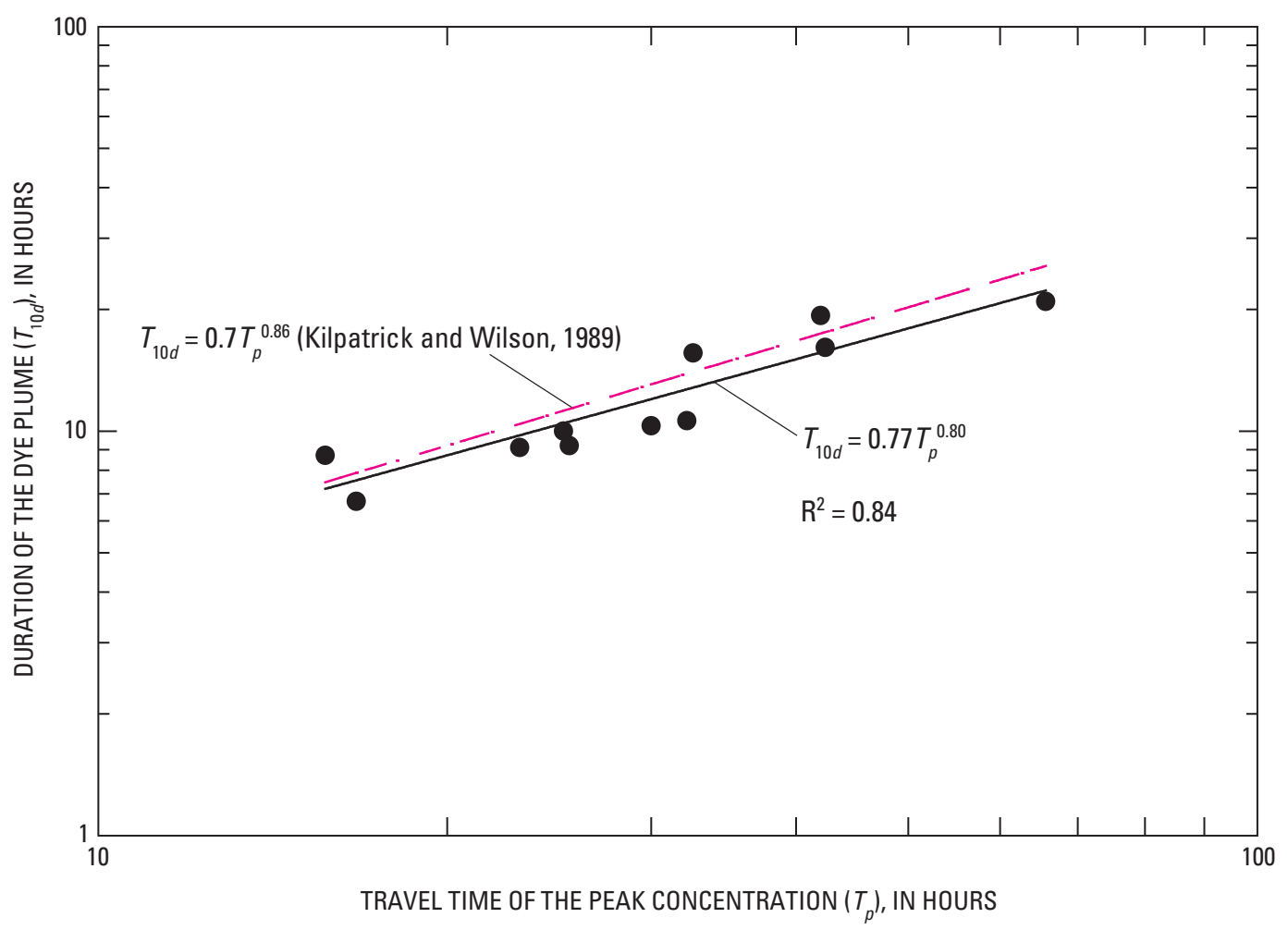

Figure 13. Relation between travel times of the peak concentration and durations of the dye plume for the Yellowstone River, Montana.

determined during this study. Velocities of the peak concentration of the dye plume calculated for this study averaged 10 percent faster than the most probable velocities and averaged 12 percent slower than the maximum probable velocities estimated from the transport model (table 5).

Estimated peak concentrations from the transport model were compared with the measured peak dye concentrations for each measurement site (table 6). The transport model estimates a most probable and maximum probable peak concentration calculated from the most probable and maximum probable streamflow velocities. With the exception of the subreaches affected by incomplete lateral mixing, the measured peak concentrations for this study were consistently smaller than the transport model estimates of most probable and maximum probable peak concentrations. Measured peak concentrations are expected to be smaller than estimates because, even though RWT dye is considered to behave as a conservative constituent, it may not completely behave in a conservative manner. Solar degradation and sorption of the dye onto the streambanks, stream bottom, and algae are expected at a limited rate (Wilson and others, 1986) and may partly account for smaller measured peak concentrations. The mass of dye passing each measurement site was calculated from the time-concentration curves and ranged from 88 to 100 percent of the mass of the dye injected. The average mass recovery for the most downstream site of each dye injection was 96 percent.

\section{Uncertainty in Estimating Mean Streamflow Velocities}

The scope of this dye-tracer study was to determine travel times, streamflow velocities, and longitudinal dispersion rates for one streamflow condition along the Yellowstone River from Lockwood to Glendive. Determination of travel times, streamflow velocities, and longitudinal dispersion rates for other streamflows would require additional dye-tracer studies; however, streamflow velocities are commonly estimated using other methods. Velocity-streamflow relations developed from routine streamflow measurments made at USGS gaging stations are commonly used to estimate mean streamflow velocities throughout a range of streamflows. Routine streamflow measurements typically are from ideal locations where streamflow is uniform and well distributed across the channel; thus, velocity-streamflow relations developed by using these measurements may not represent the mean streamflow conditions for subreaches upstream or downstream from the gage. The transport model developed by McCarthy (2006) also could be used to estimate mean streamflow velocities 


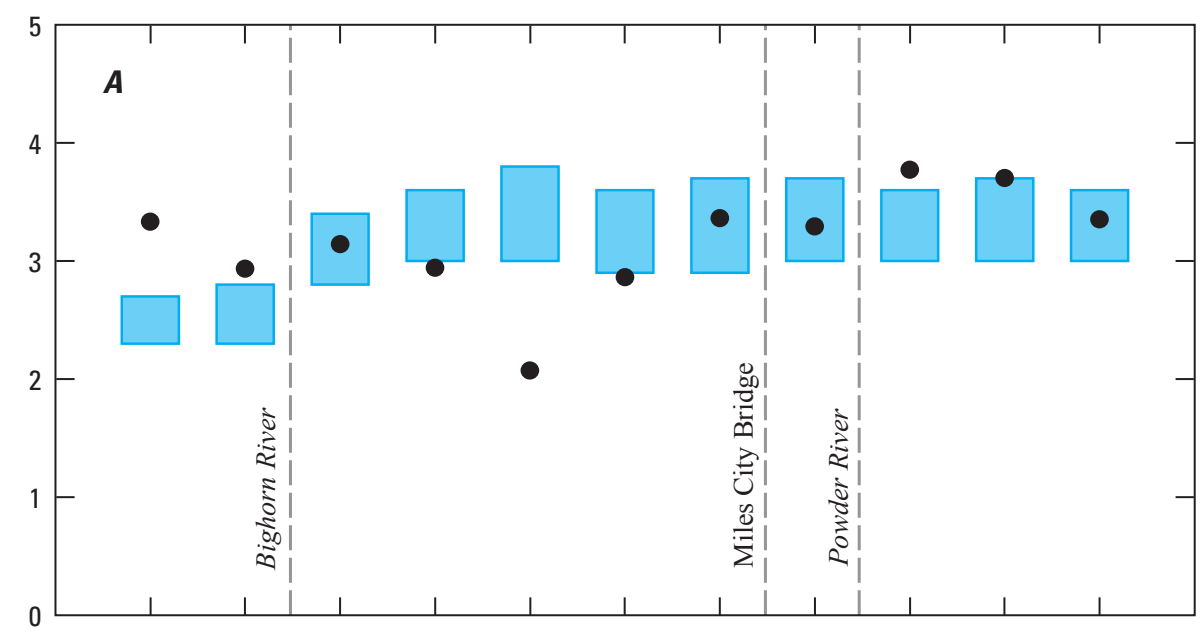

EXPLANATION
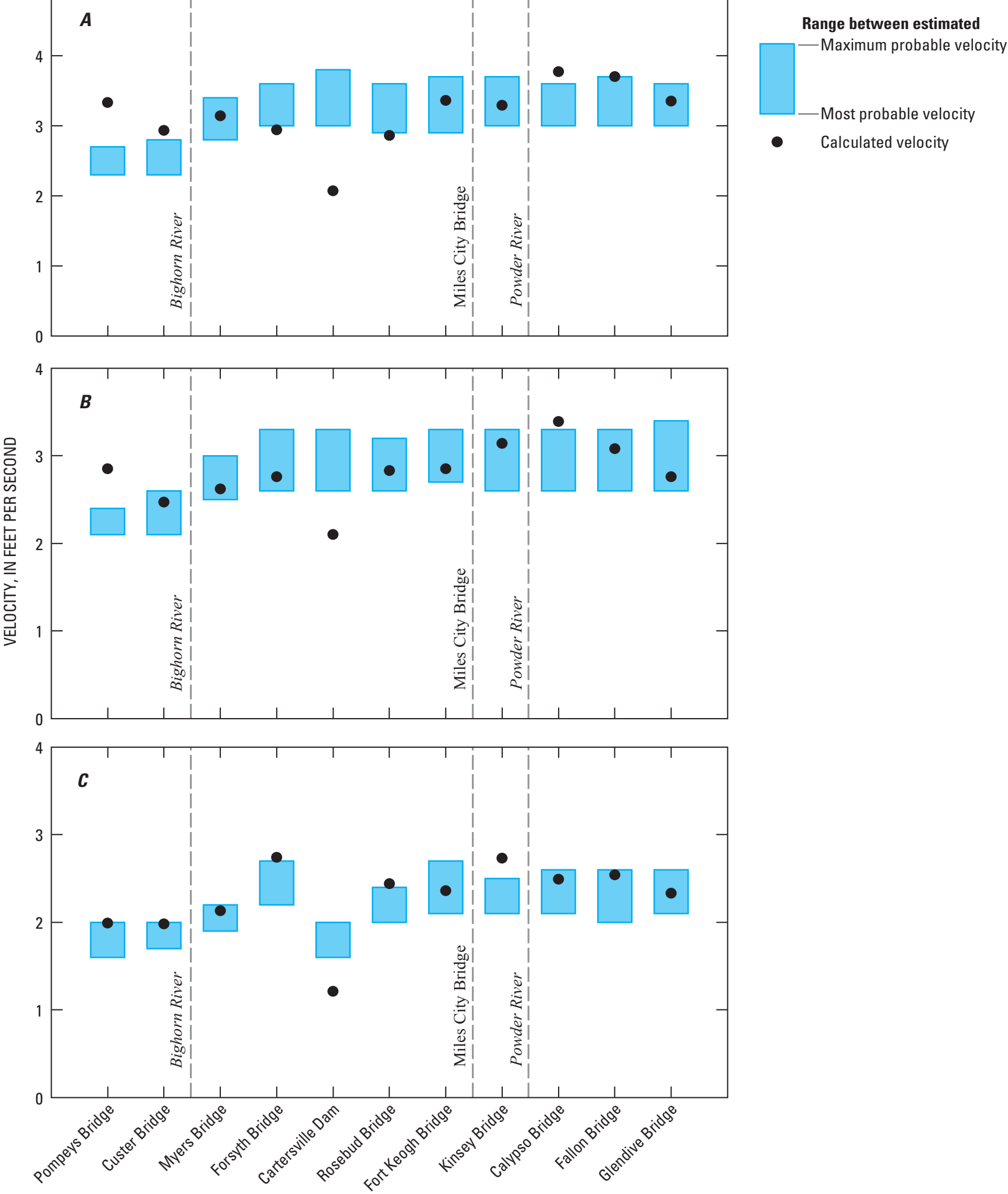

Figure 14. Calculated and estimated velocity data for subreach upstream from each site. $A$, Velocity data for leading edge of dye plume. $B$, Velocity data for peak of the dye plume. $C$, Velocity data for trailing edge at 10 percent of the peak concentration of the dye plume. Streamflows ranged from 3,490 to 3,770 cubic feet per second upstream from confluence with Bighorn River. Streamflows ranged from 6,520 to 7,570 cubic feet per second downstream from the confluence with Bighorn River. 


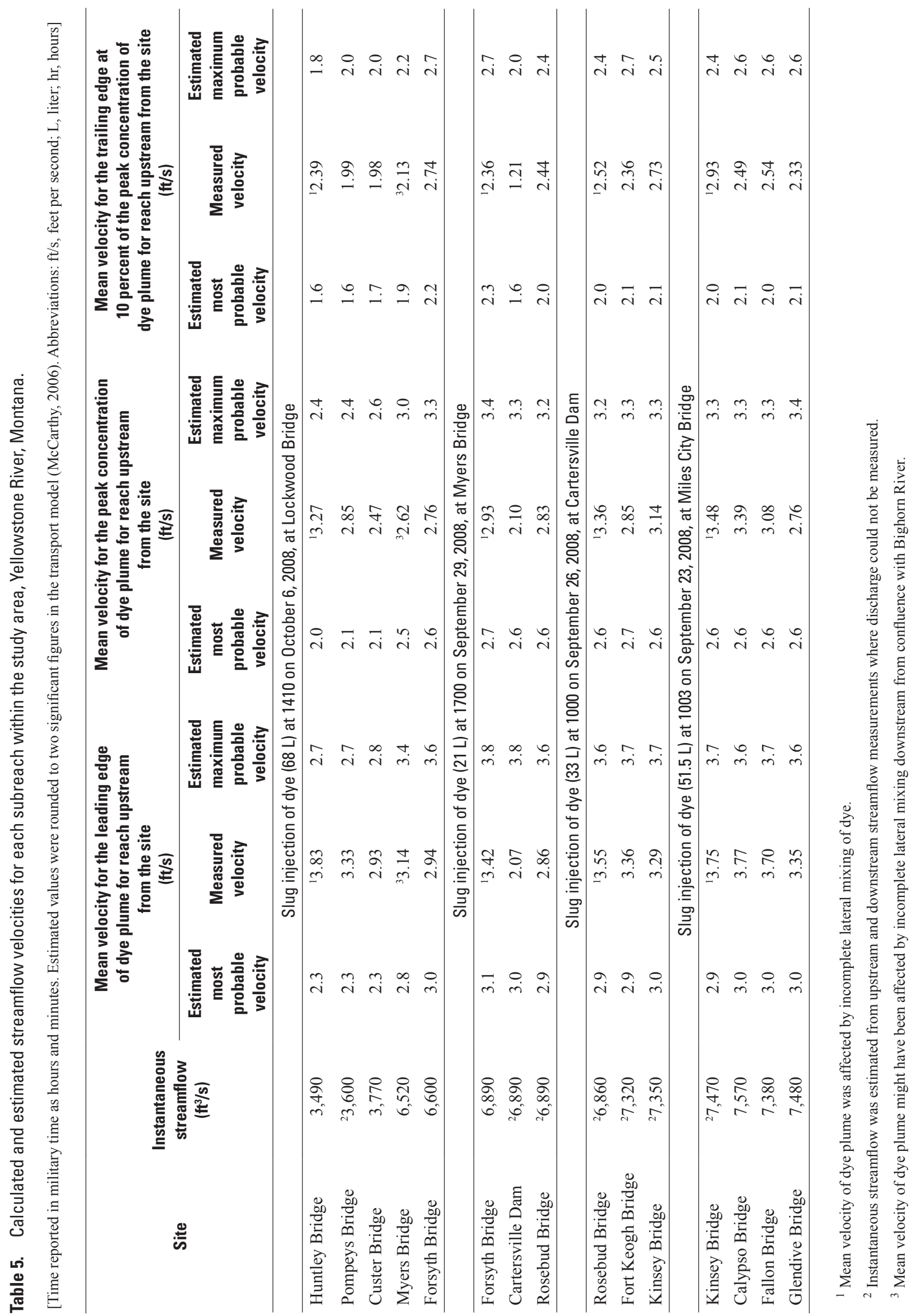


Table 6. Estimated and measured peak Rhodamine WT dye concentrations for each subreach within the study area, Yellowstone River, Montana.

[Time reported in military time as hours and minutes. Estimated values were rounded to two significant figures in the transport model (McCarthy, 2006). Abbreviations: $\mathrm{ft}^{3} / \mathrm{s}$, cubic feet per second; $\mu \mathrm{g} / \mathrm{L}$, micrograms per liter; $\mathrm{L}$, liter; hr, hours]

\begin{tabular}{|c|c|c|c|c|}
\hline \multirow[t]{2}{*}{ Site } & \multirow{2}{*}{$\begin{array}{c}\text { Instantaneous } \\
\text { streamflow } \\
\left(\mathrm{ft}^{3} / \mathbf{s}\right)\end{array}$} & \multicolumn{3}{|c|}{$\begin{array}{l}\text { Peak concentrations of Rhodamine WT dye } \\
\qquad(\mu \mathrm{g} / \mathrm{L})\end{array}$} \\
\hline & & Estimated probable & Measured & Estimated maximum \\
\hline \multicolumn{5}{|c|}{ Slug injection of dye (68 L) at 1410 on October 6,2008 , at Lockwood Bridge } \\
\hline Huntley Bridge & 3,490 & 24 & ${ }^{1} 30.4$ & 28 \\
\hline Pompeys Bridge & ${ }^{2} 3,600$ & 11 & 8.90 & 13 \\
\hline Custer Bridge & 3,770 & 6.7 & 4.63 & 7.9 \\
\hline Myers Bridge & 6,520 & 3.2 & 2.27 & 3.7 \\
\hline Forsyth Bridge & 6,600 & 2.4 & 2.05 & 2.8 \\
\hline \multicolumn{5}{|c|}{ Slug injection of dye (21 L) at 1700 on September 29, 2008, at Myers Bridge } \\
\hline Forsyth Bridge & 6,890 & 1.8 & ${ }^{1} 1.52$ & 2.1 \\
\hline Cartersville Dam & ${ }^{2} 6,890$ & 1.8 & 1.43 & 2.1 \\
\hline Rosebud Bridge & ${ }^{2} 6,890$ & 1.4 & 1.22 & 1.7 \\
\hline \multicolumn{5}{|c|}{ Slug injection of dye (33 L) at 1000 on September 26, 2008, at Cartersville Dam } \\
\hline Rosebud Bridge & ${ }^{2} 6,860$ & 6.9 & ${ }^{1} 9.27$ & 8.2 \\
\hline Fort Keogh Bridge & 27,320 & 2.3 & 2.08 & 2.8 \\
\hline Kinsey Bridge & ${ }^{2} 7,350$ & 1.9 & 1.88 & 2.3 \\
\hline \multicolumn{5}{|c|}{ Slug injection of dye (51.5 L) at 1003 on September 23, 2008, at Miles City Bridge } \\
\hline Kinsey Bridge & ${ }^{2} 7,470$ & 11 & ${ }^{1} 26.2$ & 13 \\
\hline Calypso Bridge & 7,570 & 4.3 & 4.18 & 5.2 \\
\hline Fallon Bridge & 7,380 & 3.2 & 2.82 & 3.8 \\
\hline Glendive Bridge & 7,480 & 2.2 & 1.63 & 2.7 \\
\hline
\end{tabular}

throughout a range of streamflows. The transport model uses regression equations developed from numerous dye-tracer studies conducted nationwide, but velocity-streamflow relations developed using this model may not accurately estimate mean streamflow velocities throughout a range of streamflows in the Yellowstone River.

Velocity-streamflow relations were developed by using routine streamflow measurement data from the USGS gaging stations at Billings, Forsyth, Miles City, and Glendive (water years 2005-08, http://waterdata.usgs.gov/mt/nwis). Velocitystreamflow relations also were developed for the most probable velocity and maximum probable velocity using the transport model for subreaches at or near each of the gaging stations (Lockwood Bridge to Huntley Bridge, Forsyth Bridge to Cartersville Dam, Fort Keogh Bridge to Kinsey Bridge, and Fallon Bridge to Glendive Bridge, respectively). The calculated mean streamflow velocities for the centroid of the dye plume determined for this study were plotted with the velocity-streamflow relations developed from the USGS gaging stations and the transport model (figs. 15-18). The variation in these velocity-streamflow relations emphasizes the uncertainty in estimating the mean streamflow velocity for streamflows outside of the range of streamflows measured in this study. For example, at a streamflow of $10,000 \mathrm{ft}^{3} / \mathrm{s}$, the mean streamflow velocity can range from 3.26-4.95 ft/s, 2.18-4.03 ft/s, 2.68-3.81 ft/s, and 2.96-3.95 ft/s for the subreaches upstream from Huntley Bridge, Cartersville Dam, Kinsey Bridge, and Glendive Bridge, respectively (figs. 15-18). 


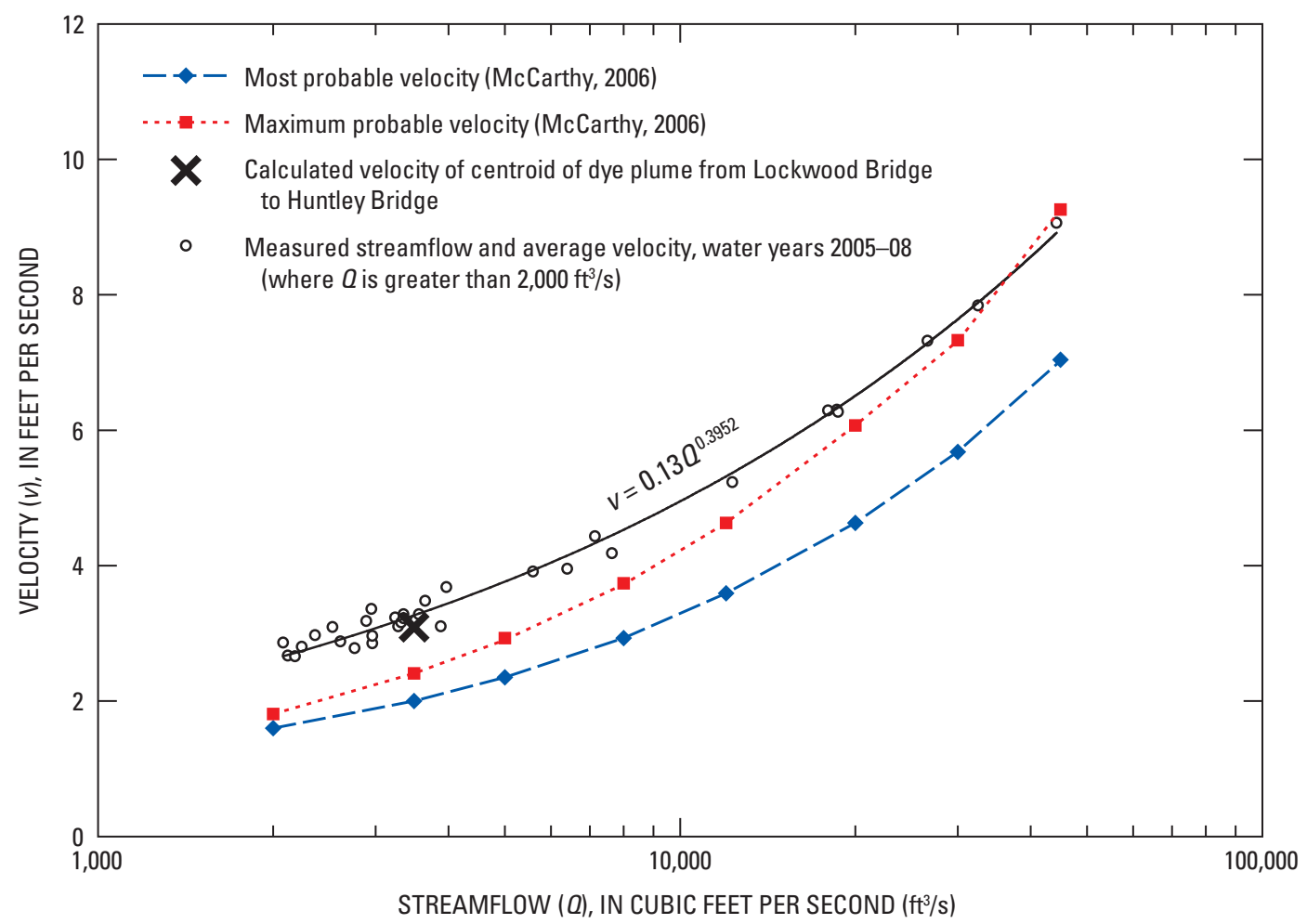

Figure 15. Calculated velocity of the centroid of the dye plume from Lockwood Bridge to Huntley Bridge and the velocity-streamflow relations developed from the transport model (McCarthy, 2006) and routine streamflow measurements for the Yellowstone River at Billings, Montana (gaging station 06214500).

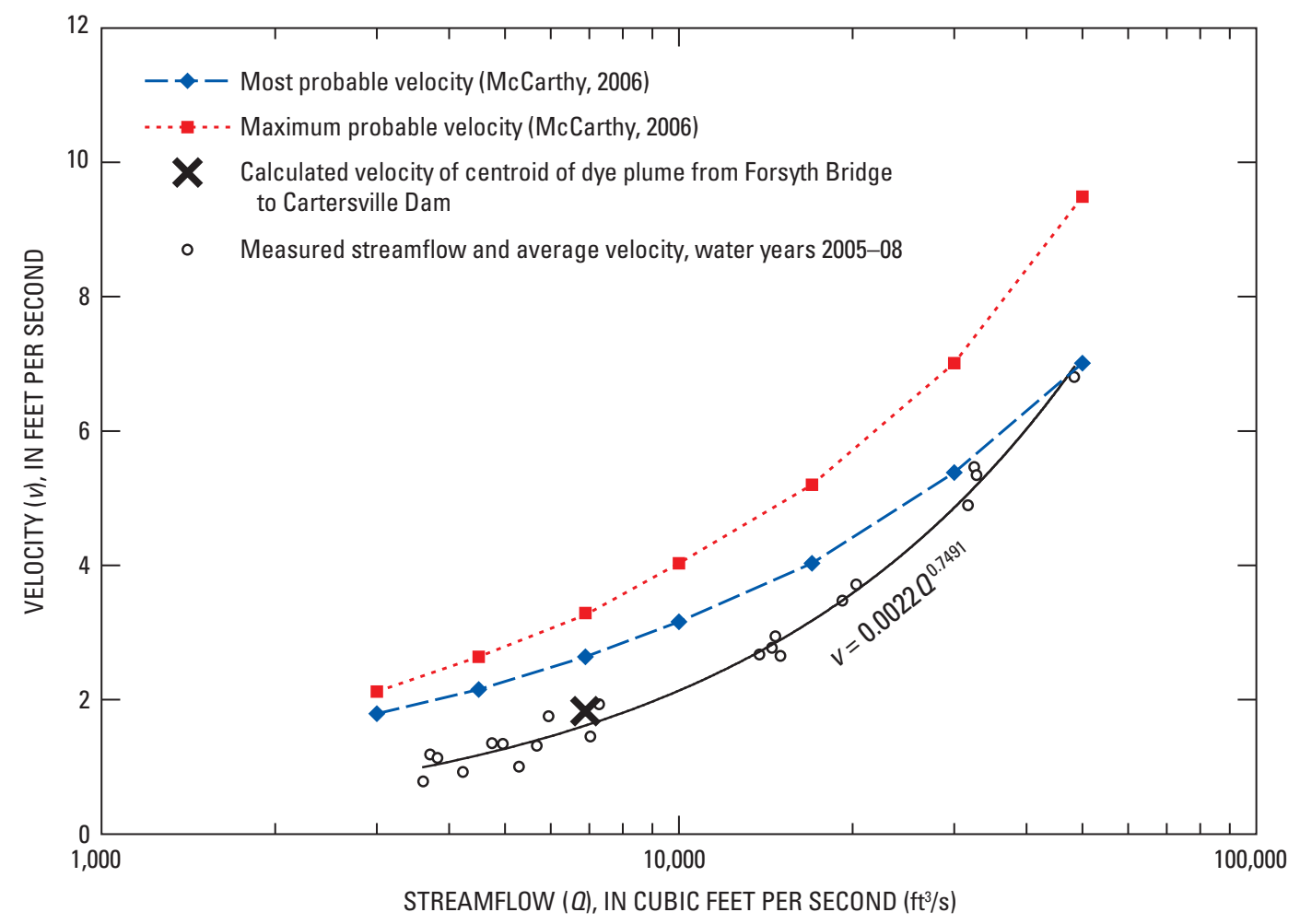

Figure 16. Calculated velocity of the centroid of the dye plume from Forsyth Bridge to Cartersville Dam and the velocity-streamflow relations developed from the transport model (McCarthy, 2006) and routine streamflow measurements for the Yellowstone River at Forsyth, Montana (gaging station 06295000). 


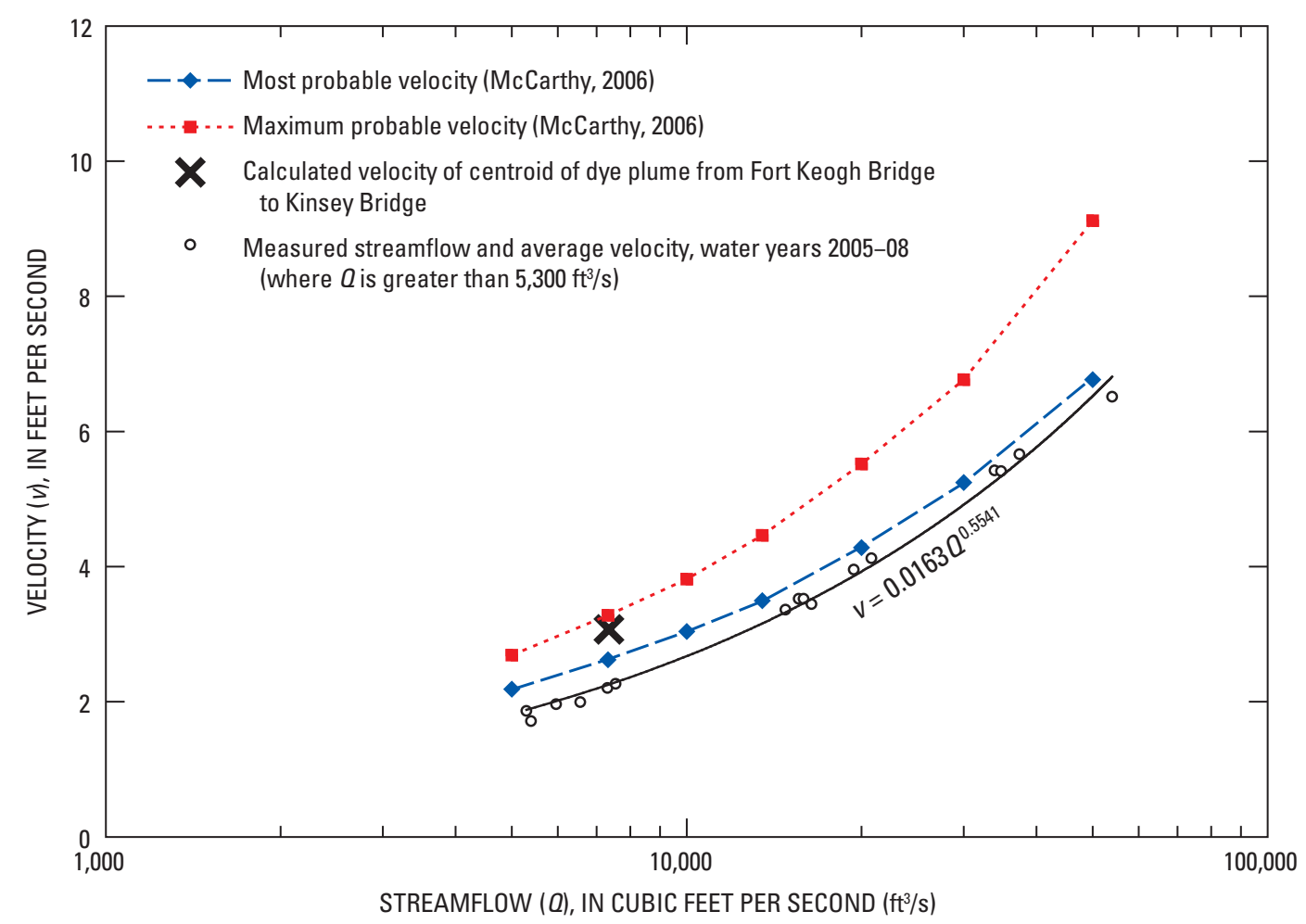

Figure 17. Calculated velocity of the centroid of the dye plume from Fort Keogh Bridge to Kinsey Bridge and the velocity-streamflow relations developed from the transport model (McCarthy, 2006) and routine streamflow measurements for the Yellowstone River at Miles City, Montana (gaging station 06309000).

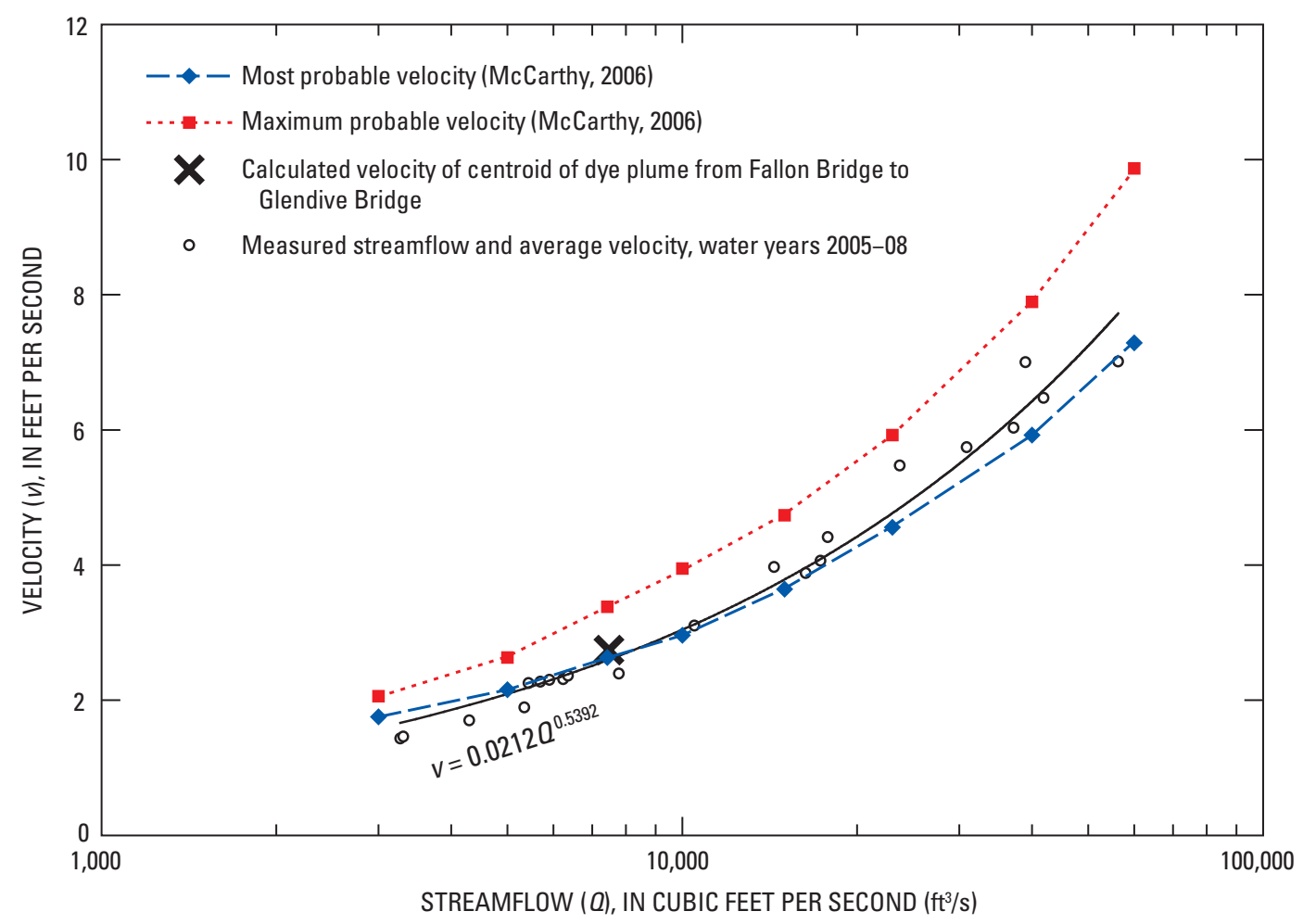

Figure 18. Calculated velocity of the centroid of the dye plume from Fallon Bridge to Glendive Bridge and the velocity-streamflow relations developed from the transport model (McCarthy, 2006) and routine streamflow measurements for the Yellowstone River at Glendive, Montana (gaging station 06327500). 


\section{Limitations of the Travel Times, Streamflow Velocities, and Longitudinal Dispersion Rates}

Data collected as part of this study reflect limited hydrologic conditions (reasonably steady streamflow) over a limited period (late September and early October 2008); therefore, the travel times, streamflow velocities, and longitudinal dispersion rates determined in this study are limited to these streamflow conditions. Streamflows ranged from 3,490 to $3,770 \mathrm{ft}^{3} / \mathrm{s}$ upstream from the confluence with the Bighorn River and ranged from 6,520 to $7,570 \mathrm{ft}^{3} / \mathrm{s}$ downstream from the confluence with the Bighorn River. Care should be exercised when estimating travel times, streamflow velocities, and longitudinal dispersion rates for streamflows other than those observed during this study. Determination of travel times, streamflow velocities, and longitudinal dispersion rates for other streamflow conditions would require additional dye-tracer studies under a variety of streamflow conditions.

\section{Summary and Conclusions}

In 2008, the U.S. Geological Survey (USGS), in cooperation with the Montana Department of Environmental Quality, initiated a dye-tracer study to measure instream travel times in the Yellowstone River. Data collected from late September and early October 2008 were used to determine the travel times, streamflow velocities, and longitudinal dispersion rates for a 266-mile reach of the Yellowstone River. The upstream end of the study reach is downstream from Billings where U.S. Highway 87 (Lockwood Bridge) crosses the Yellowstone River at about river mile 360.6 and extended approximately $266 \mathrm{mi}$ downstream to the West Bell Street Bridge (Glendive Bridge), river mile 94.6, in Glendive. Within the study reach, three major tributaries join the Yellowstone River: Bighorn River, Tongue River, and Powder River. Streamflows were reasonably steady and ranged from 3,490 to $3,770 \mathrm{ft}^{3} / \mathrm{s}$ upstream from the confluence with the Bighorn River and ranged from 6,520 to $7,570 \mathrm{ft}^{3} / \mathrm{s}$ downstream from the confluence with the Bighorn River. For this study, Rhodamine WT (RWT) dye was injected at four locations: Lockwood Bridge, Myers Bridge, Cartersville Dam, and Miles City Bridge.

Mean velocities were calculated for each subreach between measurement sites for the leading edge, peak concentration, centroid, and trailing edge at 10 percent of the peak concentration. Calculated velocities for the centroid of the dye plume for subreaches that were completely laterally mixed ranged from 1.83 to $3.18 \mathrm{ft} / \mathrm{s}$ within the study reach from Lockwood Bridge to Glendive Bridge. Excluding the subreach between Forsyth Bridge and Cartersville Dam, which is a backwater area created by the Cartersville Dam, the mean of the completely mixed centroid velocity for the entire study reach was $2.80 \mathrm{ft} / \mathrm{s}$. Similarly, the mean of the completely mixed velocities of the leading edge, peak concentration, and trailing edge at 10 percent of the peak concentration were $3.27 \mathrm{ft} / \mathrm{s}, 2.88 \mathrm{ft} / \mathrm{s}$, and $2.37 \mathrm{ft} / \mathrm{s}$, respectively.

Longitudinal dispersion of the dye plume, having no boundaries, continues indefinitely and is dependant on the stream characteristics of the reach. The longitudinal dispersion rate was estimated for subreaches by subtracting the velocity of the trailing edge of the dye plume from the velocity of the leading edge of the dye plume. Longitudinal dispersion rates of the dye plume for this study ranged from $0.06 \mathrm{ft} / \mathrm{s}$ for the subreach upstream from Forsyth Bridge to $2.25 \mathrm{ft} / \mathrm{s}$ for the subreach upstream from Calyspo Bridge for subreaches where the dye was completely laterally mixed. A relation was determined between the travel time of the peak concentration and the time for the dye plume to pass a site (duration of the dye plume). This relation can be used to estimate when the receding concentration of a potential contaminant reaches 10 percent of its peak concentration for accidental spills into the Yellowstone River.

Data from this dye-tracer study were used to evaluate velocity and concentration estimates from a transport model developed as part of an earlier USGS study. Comparison of the estimated and calculated velocities for the study reach indicate that the transport model estimates the velocities of the Yellowstone River between Huntley Bridge and Glendive Bridge with reasonable accuracy. However, differences between estimated and calculated velocities are evident. The transport model uses an average slope (about $4.7 \mathrm{ft} / \mathrm{mi}$ ) for the subreach between Lockwood and the confluence with the Bighorn River even though the stream slope varies from $7.1 \mathrm{ft} / \mathrm{mi}$ at the upstream end of this subreach to $4.1 \mathrm{ft} / \mathrm{mi}$ at the downstream end of this subreach. The variability of the stream slope in these reaches would partly account for differences between estimated velocities and calculated velocities determined during this study. Velocities of the peak concentration of the dye plume calculated for this study averaged 10 percent faster than the most probable velocities and averaged 12 percent slower than the maximum probable velocities estimated from the transport model. Measured peak RWT dye concentrations were consistently lower than the transport model estimates except for the most upstream subreach of each dye injection. The most upstream subreach of each dye injection is expected to have a higher concentration because of incomplete lateral mixing. Lower measured peak concentrations for all other sites were expected because RWT dye deteriorates when exposed to sunlight and will sorb onto the streambed and stream bottom.

Velocity-streamflow relations developed from routine streamflow measurements at USGS gaging stations and the transport model can be used to estimate mean streamflow velocities throughout a range of streamflows. The variation in these velocity-streamflow relations emphasizes the uncertainty in estimating the mean streamflow velocity for streamflows outside of the streamflows measured in this study. 


\section{Selected References}

Funkouser, J.E., and Barks, C.S., 2004, Development of a traveltime prediction equation for streams in Arkansas: U.S. Geological Survey Scientific Investigations Report 2004-5064, 17 p.

Google, Inc., 2008, Google Earth user guide, Measuring distances and areas, accessed July 15, 2008, at http://earth. google.com/intl/en/userguide/v5/ug_measuring.html.

Jobson, H.E., 1999, Contaminants in rivers and streamsprediction of travel time and longitudinal dispersion: Geneva, Switzerland, World Meteorological Organization Operational Hydrology Report no. 45, 49 p.

Kilpatrick, F.A., and Wilson, J.F., Jr., 1989, Measurement of time of travel in streams by dye tracing: U.S. Geological Survey Techniques of Water-Resources Investigations, book 3, chap. A9, 27 p.

Lundgren, R.F., and Nustad, R.A., 2008, Calibration of a water-quality model for low-flow conditions on the Red River of the North at Fargo, North Dakota, and Moorhead, Minnesota, 2003: U.S. Geological Survey Scientific Investigations Report 2008-5007, 41 p.

McCarthy, P.M., 2005, Statistical summaries of streamflow in Montana and adjacent areas, water years 1900 through 2002: U.S. Geological Survey Scientific Investigations Report 2004-5266, 317 p.

McCarthy, P.M., 2006, A computer program for estimating instream travel times and concentrations of a potential contaminant in the Yellowstone River, Montana: U.S. Geological Survey Scientific Investigations Report 2006-5057, $16 \mathrm{p}$.
Montana Department of Natural Resources and Conservation, 1976, River mile index of the Yellowstone River: Montana Department of Natural Resources and Conservation, Water Resources Division, $61 \mathrm{p}$.

Oberg, K.A., Morlock, S.E., and Caldwell, W.S., 2005, Quality-assurance plan for discharge measurements using acoustic Doppler current profilers: U.S. Geological Survey Scientific Investigations Report 2005-5183, p 35.

Office of the Federal Register, 1998, Part III, Environmental Protection Agency, Announcement of the drinking water contaminant list: Code of Federal Regulations, v. 63, no. 40, p. 10273-10287, accessed November 3, 2009, at http:// frwebgate.access.gpo.gov/cgi-bin/getpage.cgi? position $=$ all $\&$ page $=10273 \&$ dbname $=1998 \_$register .

Salas, J.D., Smith, R.A., Tobios, G.Q., III, and Heo, J.H., 2002, Statistical computing techniques in water resources and environmental engineering: Fort Collins, Colo., Department of Civil Engineering, Colorado State University, [variously paged].

Turner Designs, Inc., 2002, The 10-AU-005-CE Field fluorometer fact sheet, accessed August 18, 2008, at http://www. turnerdesigns.com/t2/doc/appnotes/998_5000.html.

Turner Designs, Inc., 2004, SCUFA user's manual, accessed August 18, 2008, at http://www.turnerdesigns.com/t2/doc/ manuals/scufa_manual.pdf.

Wilson, J.F., Cobb, E.D., and Kilpatrick, F.A., 1986, Fluorometric procedures for dye tracing: U.S. Geological Survey Techniques of Water-Resources Investigations, book 3, chap. A12, 34 p. 


\section{Appendixes}

The raw SCUFA data (appendix 1), adjusted SCUFA data (appendix 2), bench fluorometer data (appendix 3), and three-parameter log-normal data and equation parameters (appendix 4) were compiled and organized into four Excel spreadsheets (files) that each contain two worksheets. The first worksheet of each appendix contains descriptions of the headings used in each appendix. Appendixes 1-4 are located in the CD-ROM on the inside back cover of this report and can be downloaded as Excel files from http://pubs.usgs.gov/sir/2009/5261/.

Appendix 1. Raw Data from the Self-Contained Underwater Fluorescence Apparatus for Measurement Sites along the Yellowstone River, Montana.

Appendix 2. Adjusted Data from the Self-Contained Underwater Fluorescence Apparatus for Measurement Sites along the Yellowstone River, Montana.

Appendix 3. Bench Analysis of Grab Samples Measured with Turner Designs Model 10 Fluorometer for Measurement Sites along the Yellowstone River, Montana.

Appendix 4. Data and Equations for Three-Parameter Log-Normal Curves of the Self-Contained Underwater Fluorescence Apparatus and Grab-Sample Data for Measurement Sites along the Yellowstone River, Montana. 
Publishing support provided by:

Denver Publishing Service Center

For more information concerning this publication, contact: Director, USGS Montana Water Science Center

3162 Bozeman Ave.

Helena, MT 59601

(406) 457-5900

Or visit the Montana Water Science Center Web site at: http://mt.water.usgs.gov 



\section{$\frac{\mathbb{3}}{3}$}

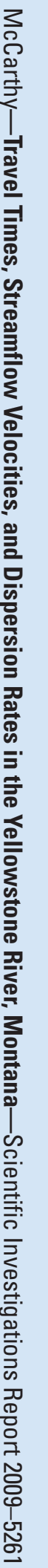

69 Printed on recycled paper

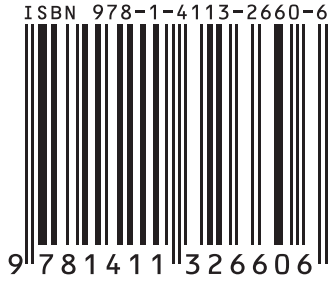

